Article

\title{
The Impact of Financial Leverage on Shareholders' Systematic Risk
}

\author{
David Yechiam Aharon $1, *(\mathbb{D})$ and Yossi Yagil ${ }^{2,3}$ \\ 1 Department of Business Administration, Ono Academic College, Kiriat Ono 5500003, Israel \\ 2 Jacobs School of Management, Department of Business Administration, University of Haifa, Haifa 3498838, \\ Israel; yyagil@univ.haifa.ac.il \\ 3 Department of Business Administration, Western Galilee College, Akko 2412101, Israel \\ * Correspondence: dudi.ah@ono.ac.il; Tel.: +972-9-8607421
}

Received: 21 October 2019; Accepted: 16 November 2019; Published: 20 November 2019

check for updates

\begin{abstract}
This paper tests the degree to which a sustainable relationship exists between financial leverage and the systematic risk of shareholders under the following capital market imperfections: corporate and personal taxes as well as risky debt and bankruptcy costs. This beta-leverage relationship has not yet been examined empirically in prior studies nor compared with the theoretical parameter values implied by well-known formulations in the literature. Using data from publicly traded American industrial firms, we found that risky debt models, rather than their corresponding risk free debt models, are more sustainable and appropriate for describing the link between equity beta and financial leverage. Our findings imply that estimating betas or unlevering betas based on risk free debt models might lead to unsustainable and inaccurate estimates of key corporate parameters such as the cost of capital, and may consequently lead to inappropriate capital budgeting decisions. In this respect, the results of this study might have consequences to the recently growing area of sustainable finance in the sense that investment decisions made by different bodies and institutions in the country are more consistent with market imperfections that exist in the economy. In other words, our findings can be in line with a sustainable financial marketplace that contributes to the economic efficiency in the long run and can be related to social well-being.
\end{abstract}

Keywords: equity risk; financial leverage; unlevered beta; market imperfections; sustainable finance

\section{Introduction}

One of the forces underlying the recent global financial crisis is the impact of debt on asset values, which can also be related to the concept of sustainable investment and the selection and management of investments. In recent years, a substantial amount of research has been devoted to environmental, social, and governance (ESG) issues and its relation to the stability of the financial system. For example, governance failures of banks and corporations contributed to the Asian and the global financial crisis resulting from poor risk management and under performance. A related issue in the context of business firms is the impact of financial leverage (namely, the proportion of debt in the capital structure) on the equity systematic risk (henceforth, beta). MM's [1,2] theoretical model dictates a positive and linear relationship between the cost of equity capital and financial leverage within the same business risk class. This theoretical foundation was later extended in the pioneering works of Hamada $[3,4]$ and Rubinstein [5], who formulated a theoretical relationship between equity betas and leverage. However, their discussions were only confined to the simple case of risk free debt and corporate taxes. Conine [6] extended Hamada and Rubinstein's theoretical formulations to the case of risky debt, while Yagil [7] expanded the theoretical formulations to the general case of both corporate and personal taxes as well as risky debt and bankruptcy costs. 
The motivation of this paper is to extend the empirical tests of the beta-leverage relationship in the literature by examining whether frictions such as default risk, corporate and personal taxes, and bankruptcy costs have an impact on the relationship between beta and financial leverage, and to realize whether risk free debt or risky debt theoretical models are a better reflection of the real relationship between beta and leverage. To accomplish this goal, we compared the observed regression coefficients to their theoretical counterparts in both risk free debt and risky debt models, and examined whether the differences between these values are statistically significant-an important insight that has not been conducted so far in this manner in the literature.

While there has been a wide range of empirical research relating beta to financial leverage and other variables (an approach that we characterize as indirect), most empirical studies have not tested the theoretical relationships directly as appears in the literature, or use a variety of estimates for the key variables such as financial leverage, taxes, and bankruptcy costs. These indirect approach-studies, which are the most common in the literature, do not test the theoretical relationships derived by Hamada [3,4], Rubinstein [5], Conine [6], and Yagil [7]. Instead, they employed indirect tests involving various statistical and econometric methods such as regression analysis. One of the main contributions of this paper is directly testing Hamada and Conine's theoretical relationships as well as Yagil's theoretical model by using both corporate and personal taxes as well as risky debt associated with bankruptcy costs. Direct empirical tests of the theoretical relationship between beta and leverage have been conducted in only a few studies such as those of Hamada [4], Bowman [8], Chance [9], and Marston and Perry [10]. However, these studies did not incorporate personal taxes, risky debt, and bankruptcy costs directly in their empirical examinations. Moreover, we did not only test whether there was a positive or negative relationship between equity beta and leverage, but we also compared the values predicted by the theoretical model to the actual values.

Given this empirical gap, this study, to the best of our knowledge, presents a first attempt to directly test the theoretical relationship between beta and leverage by including both corporate and personal taxes as well as risky debt and bankruptcy costs. We maintain that such an examination will quantify the effect of market imperfections in the beta-leverage relationship. Examining this issue is important for several reasons. Most finance textbooks use Hamada and Rubinstein's risk free debt formulations. Should Hamada's adjustment for leverage fail to hold in practice, the betas would be biased and unsustainable, leading to inaccurate estimates of the cost of capital, and consequently may lead to incorrect capital budgeting decisions. In cases in which performance measures such as those of Jensen and Treynor are applied to the company as a whole, an overall beta for the firm must be calculated, which is a weighted average of both the debt beta and the equity beta. This calculation is particularly important for evaluating non-publicly traded companies for which beta unlevering is needed. The results of our study imply that the more accurate and sustainable unlevering procedure is the one involving risky rather than risk free debt.

The results of this study may have implications on the recently growing area of sustainable finance in the sense that investment decisions made by different corporations and economic institutions are more consistent with the market imperfections above-mentioned that exist in the economy. Applying the risk-leverage relationship found in this study is more robust than previous similar relationships, and may have an impact on investing and the development of the financial system in a more sustainable way.

The remainder of this study proceeds as follows. Section 2 reviews the previous theoretical research and empirical studies. Section 3 presents the hypotheses to be tested and the expected results. Section 4 describes the sample and the methods used to measure the variables. Section 5 presents the empirical results and robustness tests, and Section 6 summarizes the main conclusions and implications of the study. 


\section{Prior Works}

Work in the field of the beta-leverage relationship can be divided into theoretical and empirical studies. Based on Modigliani and Miller [1,2], Hamada [3,4] and Rubinstein [5] produced the earliest theoretical works. On the other hand, most of the empirical studies relate the systematic risk (beta) to numerous explanatory variables, but they are typically subject to the criticism of no theory, which relates beta to several independent variables. Only a few empirical papers have tested the beta-leverage theoretical relationship that was initially suggested by Hamada and Rubinstein.

Based on Modigliani and Miller's capital structure theory, the required return on equity of a levered firm increases linearly with its debt to equity ratio. Hamada [3,4] and Rubinstein [5] demonstrated that when a firm issues debt, its beta should increase, because the firm has taken on a financial risk in addition to its business risk. Accordingly, they develop a theoretical relationship between the systematic risk of the equity (beta) and the financial leverage of the firm under both perfect capital markets and the case where corporate taxes are the only type of market imperfection. Rubinstein [5] interpreted the unlevered firm's common stock beta in terms of operating risk, showing that it reflects the combined effects of the purely systematic influence of economy-wide events and the uncertainty surrounding the firm's operating efficiency.

The beta-leverage relationship initially suggested by Hamada and Rubinstein is commonly used in practice to help determine the levered beta as well as the value of the firm and its expected return and risk. Conine [6] extended the beta-leverage relationship to the case of risky debt, but his adjustment did not include personal taxes and bankruptcy costs. Given that in reality, personal taxes and bankruptcy costs do exist in addition to corporate taxes, Yagil [7] theoretically formulated the beta-leverage relationship when both corporate and personal taxes exist, and debt is risky and is associated with bankruptcy costs.

The empirical studies of the beta-leverage relationship can be classified into two types of tests: indirect and direct. Indirect tests, which are more common, use regression models to estimate the beta-leverage relationship by linking the beta to a group of explanatory variables such as size, profitability, liquidity, and financial leverage. In contrast, the direct type of empirical studies tests the theoretical beta-leverage relationship suggested in the literature directly.

The general approach of indirect tests has been to combine financial leverage with other explanatory variables in order to explain the degree of equity risk (e.g., Beaver, Kettler and Scholes [11]; Bildersee [12]; Myers [13]; Gahlon and Gentry [14]; Mandelker and Rhee [15]; Darrat and Mukherjee [16]). While in most cases (though not uniformly), the type of research documents a positive beta-leverage relationship, these studies are also criticized by the fact of no theory, which supports or relates their tested variables. Moreover, there is no consensus about the factors that should be added to financial leverage as explanatory variables, because there is no theory that relates the beta to the specific explanatory variables directly.

Much less common and much more limited in scope are direct studies such as those of Hamada [4], Bowman [8], Chance [9], and Marston and Perry [10] that have estimated the theoretical beta-leverage relationship directly. Using a sample of 304 firms from 1947-1968, Hamada [4] showed that the debt to equity ratio had a significant effect on the shareholders' systematic risk. He measured the levered and unlevered systematic risk of the same stocks by using their observed returns and their revised returns. In other words, he measured the rate of return to equity holders over the same time period if the firm had no debt or preferred stock in its capital structure. By comparing the systematic risk in both cases, where the only difference between them is probably attributable to financial leverage, he revealed that levered systematic risk is higher.

Based on data from 92 firms from seven industries, Bowman [8] also provided direct empirical evidence about the beta-leverage relationship. His results indicate that financial leverage has a significant impact on equity risk. He also tested the beta-leverage relationship by using dummy variables for sectors to gauge homogeneous business risk within the sample firms. The results remain 
similar excluding the R-squared value that probably increases due to the business risk differentiation. Still, he did not address the issue of market imperfections in his empirical tests.

Chance [9] conducted a direct regression analysis of the beta-leverage relationship. He also used Hamada's method for estimating unlevered betas $\left(\beta_{U}\right)$. First, he measured the levered beta estimates and used Hamada's method for estimating the unlevered betas. His initial results were in accordance with Hamada's findings. He found that the mean value of the levered beta estimate was considerably larger than the mean of the unlevered beta estimate. Then, Chance divided his sample firms into four homogeneous risk classes according to four ranges of the unlevered beta $(0.65-0.85,0.65-0.75$, $0.7-0.8$, and $0.75-0.85)$, and tested Hamada's relationship directly. Moreover, he tested how closely his observed slope was to Hamada's implied theoretical slope $\left[\beta_{U}\left(1-T_{C}\right)\right]$, where $T_{C}$ is the corporate tax rate. Chance's results indicated a positive beta-leverage relationship that supports Hamada's equation. Second, Chance concluded that the penalty for financial leverage, which is captured by the implied slope using Hamada's equation compared to the actual slope's results, was higher. However, the difference was not consistently significant. These results, however, were based on relatively small, overlapping samples and were confined to the 1974 to 1978 period.

Marston and Perry [10] conducted a study that tested the relationship between beta and leverage directly. Their approach involved a series of cross-sectional analyses across a sample of US firms in selected two-digit and four-digit SIC (Standard Industrial Classification) industry classifications. Generally, their results suggest a positive relationship, with stronger results when controlling for business risk using a four-digit classification. Like Chance [9], they tested how close the observed slope was to that of Hamada and Rubinstein and concluded that the techniques that are commonly applied to unlevering beta tend to over-penalize beta when higher levels of financial leverage are used.

However, each of these four direct empirical tests suffered from several deficiencies. First, they did not incorporate personal taxes and bankruptcy costs. Second, they did not estimate the variables representing taxes and debt riskiness directly. Third, their incorporation of risky debt was only implicit, and not explicit within the beta-leverage relationship. Finally, they were relatively old, containing no data after 1988.

This study attempts to fill this gap by estimating the beta-leverage relationship directly under various types of market imperfections that have not been considered previously. Specifically, it explores the beta-leverage relationship under corporate and personal taxes as well as risky debt and bankruptcy costs. It also uses several measures for the key variables, allowing us to test the degree of robustness of the results obtained.

\section{The Theoretical Framework and Hypotheses}

We tested seven beta-leverage models in this study. The first three models are for the case of risk free debt (Case a). The subsequent four models are for the case of risky debt (Case b). Model (1) (both 1a and 1b) is for the case of perfect capital markets, Model (2) (both 2a and 2b) is for the case where corporate taxes are the only type of market imperfection, Model (3) (both 3a and 3b) is for the case of both corporate and personal taxes, while Model (4b) also incorporates bankruptcy costs. The cross-sectional equations governing these models appear below:

Case (a): Risk Free Debt Models

$$
\begin{gathered}
\beta_{\mathrm{E}, \mathrm{i}}=\beta_{\mathrm{U}, \mathrm{i}}+\beta_{\mathrm{U}, \mathrm{i}}[\mathrm{L}]_{\mathrm{i}}+\mathrm{u}_{\mathrm{i}} \\
\beta_{\mathrm{E}, \mathrm{i}}=\beta_{\mathrm{U}, \mathrm{i}}+\beta_{\mathrm{U}, \mathrm{i}}\left[\left(1-\mathrm{T}_{\mathrm{C}}\right) \mathrm{L}\right]_{\mathrm{i}}+\mathrm{u}_{\mathrm{i}} \\
\beta_{\mathrm{E}, \mathrm{i}}=\beta_{\mathrm{U}, \mathrm{i}}+\beta_{\mathrm{U}, \mathrm{i}}[\mathrm{TL}]_{\mathrm{i}}+\mathrm{u}_{\mathrm{i}} .
\end{gathered}
$$

Case (b): Risky Debt Models

$$
\beta_{E, i}=\beta_{U, i}+\left[\left(\beta_{U}-\beta_{D}\right) L\right]_{i}+u_{i}
$$




$$
\begin{gathered}
\beta_{E, i}=\beta_{U, i}+\left[\left(\beta_{U}-\beta_{D}\right)\left(1-T_{C}\right) L\right]_{i}+u_{i}, \\
\beta_{E, i}=\beta_{U, i}+\left[\left(\beta_{U}-\beta_{D}\right) T L\right]_{i}+u_{i}, \\
\beta_{E, i}=\beta_{U, i}+\left[\left(\beta_{U}(1+q / T)-\beta_{D}\right) T L\right]_{i}+u_{i},
\end{gathered}
$$

where $\beta$ is the systematic risk (beta) coefficient of the equity; $L$ is the financial leverage of the firm; $T$ is the tax factor and is given by $T=\left(1-T_{C}\right)\left(1-T_{E}\right) /\left(1-T_{D}\right)$, where $T_{C}, T_{E}$ and $T_{D}$ are the tax rates applicable to the corporation, equity holders, and debt holders, respectively; $\mathrm{q}$ is the bankruptcy costs coefficient and is given by $q=C / D$, where $C$ is the expected value of the bankruptcy costs; and $D$ is the value of the debt. The subscripts $U$ and $E$ represent the unlevered firm and the equity of the levered firm, respectively.

Based on the brief theoretical review outlined in the previous section, this study aimed at testing the hypothesis that the actual beta-leverage relationship corresponds to the risky debt models rather than to the risk free debt models, particularly under different types of market imperfections such as those in Yagil [7]. Model (4b), derived from Yagil [7], states that the systematic risk coefficient of the common equity $\left(\beta_{\mathrm{E}}\right)$ is given by the sum of the unlevered beta $\left(\beta_{\mathrm{U}}\right)$ and the leverage $(\mathrm{L})$ multiplied by a positive coefficient given by $\left(\beta_{U}(1+q / T)-\beta_{D}\right) T$.

The direct estimated version of Model (4b) is the following regression equation (Equation (5)):

$$
\beta_{\mathrm{E}, \mathrm{i}}=\gamma_{0}+\gamma_{1}\left[\left(\beta_{\mathrm{U}}(1+\mathrm{q} / \mathrm{T})-\beta_{\mathrm{D}}\right) \mathrm{TL}\right]_{\mathrm{i}}+\varepsilon_{\mathrm{i}},
$$

By the null hypothesis $\left(\mathrm{H}_{0}\right): \gamma_{0}=\beta_{\mathrm{U}}$, and, $\gamma_{1}=1$.

Model (4b) is the general expression that incorporates both taxes and bankruptcy costs. In the special case of risk free debt, Model (4b) reduces down to Model (3a), and the estimated regression equation is given by Equation (6).

$$
\beta_{\mathrm{E}, \mathrm{i}}=\gamma_{0}+\gamma_{1}[\mathrm{TL}]_{\mathrm{i}}+\varepsilon_{\mathrm{i}},
$$

where $\mathrm{H}_{0}: \gamma_{0}=\beta_{\mathrm{U}}$, and, $\gamma_{1}=\beta_{\mathrm{U}}$. Given that in the real world debt is usually risky, $\gamma_{1}$ should be equal to 1 , which is the theoretical value in the direct estimated regression of Model (4b) given by Equation (5), rather than $\beta_{U}$, which is the theoretical value in the direct estimated regression of Model (3a) given by Equation (6). This estimation method involves the comparison of the observed regression $\gamma_{0}, \gamma_{1}$ with their theoretical counterparts $\gamma_{0}{ }^{*}, \gamma_{1}^{*}$. For Equation (5), for example, $\gamma_{1}$ should be equal to $1\left(\gamma_{1}^{*}\right)$, because the term in the squared brackets serves as the explanatory variable. Similarly, $\gamma_{0}$ should be equal to $\beta_{\mathrm{U}}\left(\gamma_{0}^{*}\right)$, where $\beta_{\mathrm{U}}$ is derived from the theoretical Model $(4 \mathrm{~b})$.

In the absence of bankruptcy costs, Model (4b) reduces down to Model (3b), and the estimated regression equation is given by Equation (7):

$$
\beta_{\mathrm{E}, \mathrm{i}}=\gamma_{0}+\gamma_{1}\left[\left(\beta_{\mathrm{U}}-\beta_{\mathrm{D}}\right) \mathrm{TL}\right]_{\mathrm{i}}+\varepsilon_{\mathrm{i}}
$$

and by $\mathrm{H}_{0}: \gamma_{0}=\beta_{\mathrm{U}}$, and, $\gamma_{1}=1$. Therefore, the next hypothesis is that given that debt in reality is risky, $\gamma_{0}$ and $\gamma_{1}$ will approximate the theoretical values given by Model (3b) rather than their corresponding values in the risk free debt Model (3a). In other words, $\gamma_{1}$ in Equation (7) will approximate 1, which is the theoretical value of $\gamma_{1}$ in Equation (7), rather than that of $\beta_{U}$, which is the theoretical value of $\gamma_{1}$ in Equation (6).

Similarly, in the absence of both personal taxes and bankruptcy costs, Model (4b) reduces down to Model ( $2 b)$, and the estimated regression equation is given by Equation (8):

$$
\beta_{\mathrm{E}, \mathrm{i}}=\gamma_{0}+\gamma_{1}\left[\left(\beta_{\mathrm{U}}-\beta_{\mathrm{D}}\right)\left(1-\mathrm{T}_{\mathrm{C}}\right) \mathrm{L}\right]_{\mathrm{i}}+\varepsilon_{\mathrm{i}}
$$

And by $\mathrm{H}_{0}: \gamma_{0}=\beta_{\mathrm{U}}$, and, $\gamma_{1}=1$. 
In the case of a perfect capital market assuming risky debt, Model (4b) reduces down to Model (1b), and the estimated regression equation is given by Equation (9):

$$
\beta_{\mathrm{E}, \mathrm{i}}=\gamma_{0}+\gamma_{1}\left[\left(\beta_{\mathrm{U}}-\beta_{\mathrm{D}}\right) \mathrm{L}\right]_{\mathrm{i}}+\varepsilon_{\mathrm{i}},
$$

And by $\mathrm{H}_{0}: \gamma_{0}=\beta_{\mathrm{U}}$, and, $\gamma_{1}=1$.

Finally, in the case of both risk free debt and the absence of personal taxes, Model (4b) reduces down to Model (2a). Furthermore, Equation (10) is the corresponding estimated regression, which is similar to Hamada's (4) and Rubinstein's (5) expressions:

$$
\beta_{\mathrm{E}, \mathrm{i}}=\gamma_{0}+\gamma_{1}\left[\left(1-\mathrm{T}_{\mathrm{C}}\right) \mathrm{L}\right]_{\mathrm{i}}+\varepsilon_{\mathrm{i}},
$$

By the null hypothesis $\left(\mathrm{H}_{0}\right): \gamma_{0}=\beta_{\mathrm{U}}$, and, $\gamma_{1}=\beta_{\mathrm{U}}$.

Once again, given that in reality debt is risky, the $\gamma_{0}, \gamma_{1}$ coefficients should be the closest to the coefficient of $L$ in Case (b), which includes risky debt models, rather than the risk free models described above in Case (a). Moreover, given that in reality personal taxes exist, and debt is risky and is associated with bankruptcy costs, Model (4b) is hypothesized to have the closest $\gamma_{0}, \gamma_{1}$ coefficients compared to the other expressions.

To summarize, the central hypothesis is that the empirical OLS intercept and slope coefficients $\left(\gamma_{0}, \gamma_{1}\right)$ given in Equation (5) will reflect the existence of corporate taxes and personal taxes as well as the risky debt and bankruptcy costs in the theoretical beta-leverage expression in Model (4b).

\section{Data and Variables Measurement}

\subsection{Data and Construction of the Sample}

We obtained our data from two sources: the COMPUSTAT database for the financial data and the Yahoo stock screener website for the stock returns in the industrial sector, which represents a broad business risk class.

Due to data availability, the research sample of firms ended in 2007, given that the subscription of the University of Haifa to COMPUSTAT ended in January 2008 (which in fact is December 2007). Consequently, the 5-year time period preceding January 2008 was employed; namely, 2003-2007. The rationale was to test the beta-leverage relationship for sensitivity purposes five times; that is, in each of the five years in the sample. Since the empirical investigation presented in this study has not been undertaken in the literature yet, we think that conducting it five times in each of the five years of the sample can contribute to our knowledge, even in the absence of more recent data. In the subsequent summary section, we note that a valuable extension of this study can be the application of the empirical method suggested in this study to more recent years. The initial sample consisted of all 306 firms from the industrial sector covered by COMPUSTAT. We then required the complete data for each of the companies in the sample and for each of the sample years. This additional screening procedure reduced our sample down to 182 firms.

\subsection{Measurement of Variables}

To test the theoretical models outlined above, we estimated the following variables: the financial leverage $(\mathrm{L})$, the common equity systematic risk $\left(\beta_{\mathrm{E}}\right)$, the business systematic risk (unlevered beta, $\left.\beta_{\mathrm{U}}\right)$, the debt systematic risk $\left(\beta_{D}\right)$, the corporate tax rate $\left(T_{C}\right)$, the tax rate applicable to the debt holders $\left(T_{D}\right)$, and to the equity holders $\left(\mathrm{T}_{\mathrm{E}}\right)$, and finally the bankruptcy costs factor $(\mathrm{q})$. In this section, we review our proxies and measurements of the variables followed by a discussion of the relevant empirical literature.

\subsubsection{The Equity Systematic Risk $\left(\beta_{\mathrm{E}}\right)$}

Following the standard approach in the literature, we estimated the equity's systematic risk $\left(\beta_{\mathrm{E}}\right)$ using the so-called market model. This model involves a regression of the stock's rate of return against 
the market index's rate of return. We used 60 monthly returns for both the stock and the market index. Given that the sample consisted of NYSE (New York Stock Exchange) stocks, the market index employed here was the NYSE Composite Index. Details of the descriptive statistics are reported in Table 1 and will be discussed in Section 5 .

Table 1. Descriptive statistics of the key variables: equity risk and financial leverage.

\begin{tabular}{|c|c|c|c|c|c|c|}
\hline$\beta_{E}$ & Mean & Med & SD & $\mathrm{CV}$ & Min & Max \\
\hline 2007 & 1.31 & 1.20 & 0.78 & 0.60 & -0.34 & 4.78 \\
\hline 2006 & 1.15 & 1.02 & 0.73 & 0.64 & -0.56 & 4.91 \\
\hline 2005 & 1.14 & 1.03 & 0.75 & 0.66 & -0.62 & 4.60 \\
\hline 2004 & 1.05 & 0.98 & 0.70 & 0.66 & -0.63 & 4.37 \\
\hline 2003 & 1.01 & 0.93 & 0.67 & 0.66 & -0.44 & 4.16 \\
\hline Mean & 1.13 & 1.03 & 0.73 & 0.64 & -0.52 & 4.56 \\
\hline $\operatorname{Lev}_{1}$ & Mean & Med & SD & $\mathrm{CV}$ & Min & Max \\
\hline 2007 & 0.77 & 0.43 & 1.14 & 1.48 & 0.00 & 7.94 \\
\hline 2006 & 0.81 & 0.44 & 1.18 & 1.46 & 0.00 & 7.94 \\
\hline 2005 & 0.80 & 0.47 & 1.09 & 1.37 & 0.00 & 8.33 \\
\hline 2004 & 0.88 & 0.50 & 1.23 & 1.40 & 0.00 & 8.59 \\
\hline 2003 & 0.92 & 0.59 & 1.23 & 1.34 & 0.00 & 7.82 \\
\hline Mean & 0.84 & 0.49 & 1.17 & 1.41 & 0.00 & 8.12 \\
\hline $\operatorname{Lev}_{2}$ & Mean & Med & SD & $\mathrm{CV}$ & Min & Max \\
\hline 2007 & 0.40 & 0.22 & 0.64 & 1.59 & 0.00 & 5.39 \\
\hline 2006 & 0.46 & 0.24 & 0.75 & 1.65 & 0.00 & 6.12 \\
\hline 2005 & 0.51 & 0.27 & 0.80 & 1.57 & 0.00 & 6.11 \\
\hline 2004 & 0.57 & 0.34 & 0.81 & 1.43 & 0.00 & 5.19 \\
\hline 2003 & 0.59 & 0.37 & 0.78 & 1.32 & 0.00 & 5.95 \\
\hline Mean & 0.51 & 0.29 & 0.76 & 1.51 & 0.00 & 5.75 \\
\hline $\mathrm{Lev}_{3}$ & Mean & Med & SD & $\mathrm{CV}$ & Min & Max \\
\hline 2007 & 1.56 & 1.01 & 1.63 & 1.05 & 0.13 & 9.00 \\
\hline 2006 & 1.61 & 1.05 & 1.69 & 1.05 & 0.15 & 9.00 \\
\hline 2005 & 1.60 & 1.09 & 1.59 & 0.99 & 0.13 & 9.00 \\
\hline 2004 & 1.71 & 1.15 & 1.73 & 1.01 & 0.15 & 9.00 \\
\hline 2003 & 1.78 & 1.20 & 1.75 & 0.98 & 0.15 & 9.00 \\
\hline Mean & 1.65 & 1.10 & 1.68 & 1.02 & 0.14 & 9.00 \\
\hline $\operatorname{Lev}_{4}$ & Mean & Med & SD & $\mathrm{CV}$ & Min & Max \\
\hline 2007 & 0.82 & 0.55 & 0.99 & 1.21 & 0.04 & 8.44 \\
\hline 2006 & 0.93 & 0.61 & 1.13 & 1.22 & 0.04 & 9.00 \\
\hline 2005 & 1.03 & 0.66 & 1.21 & 1.18 & 0.05 & 9.00 \\
\hline 2004 & 1.13 & 0.80 & 1.24 & 1.10 & 0.06 & 8.20 \\
\hline 2003 & 1.19 & 0.85 & 1.22 & 1.02 & 0.06 & 7.42 \\
\hline Mean & 1.02 & 0.69 & 1.16 & 1.15 & 0.05 & 8.41 \\
\hline
\end{tabular}




\subsubsection{Financial Leverage (L)}

The literature suggests a broad spectrum of financial leverage proxies including market and book measures for equity and debt. Lin et al. [17] defined financial leverage as total debt divided by total debt plus book value of equity. Vo [18] and Kini et al. [19] used both the book and market value of leverage. Bărbuță-Mișu et al. [20] estimated financial leverage as the ratio of total liabilities of the firm to shareholder funds, while Di Pietro et al. [21] measured leverage as the total financial debt to total debt plus equity. Lassala et al. [22] defined leverage as the ratio of total debt to equity. Saretto and Tookes [23] defined the book leverage as total debt (long-term debt plus debt in current liabilities) divided by the book value of assets, and market leverage as total debt divided by firm value, where firm value is defined as the book value of assets, minus the book value of common equity, plus the market value of equity, plus the book value of deferred taxes. Denis and McKeon [24] used the total debt over total debt plus the market value of equity. Giroud, Mueller, and Westerkamp [25] defined the market measure of financial leverage as the ratio of the book value of total debt to the book value of assets. George and Whang [26] used the ratio of the book value of long-term debt to the book value of assets, while Brav [27] used the ratio of short-term debt plus long-term debt (hereafter, LTD) to total assets. Lemmon, Roberts, and Zender [28] defined the financial leverage ratio in both the book and market values. Book leverage is the ratio of total debt to book assets, and market leverage is as Denis and McKeon [24] measured it.

Chang and Dasgupta [29] computed the ratio of book debt to total assets minus book debt. Frank and Goyal [30] used the ratio of LTD to the market value of assets as well as to the book value of assets. Alternatively, they replaced LTD with total debt in the leverage numerator. Billet, King, and Mahuer [31] calculated the ratio of LTD plus total current liabilities to total assets plus the total market value of equity minus the book value of equity. Barclays, Morellec, and Smith [32], and Fama and French [33] measured leverage as the ratio of the book value of total debt divided by the book value of assets. Molina [34] used the ratio of LTD to the book value of assets and the ratio of total debt to total assets minus the book value of equity plus the market value of equity.

To account for the possibility of potential measurement errors, we followed Aharon and Yagil [35, 36], and used four estimates for the financial leverage, which we generally defined as the ratio of debt over equity. In two estimates, debt is measured as LTD or LTD plus current liabilities. We also used both the book and the market value of the equity. Doing so resulted in four estimates of financial leverage: (1) $\mathrm{Lev}_{1}=\mathrm{LTD} /$ Equity $_{\mathrm{BV}}$; (2) $\mathrm{Lev}_{2}=\mathrm{LTD} /$ Equity $_{\mathrm{MV}}$; (3) $\mathrm{Lev}_{3}=(\mathrm{LTD}+\mathrm{CL}) /$ Equity $_{\mathrm{BV}}$, and (4) $\mathrm{Lev}_{4}=(\mathrm{LTD}+\mathrm{CL}) /$ Equity ${ }_{\mathrm{MV}}$, where Lev denotes financial leverage, LTD is long-term debt, Equity is the value of common equity, CL is current liabilities, and the subscripts BV and MV stand for book and market values, respectively. Equity ${ }_{M V}$ includes common equity in MV given by the product of the number of common shares outstanding and the mean value of the 12 monthly closing stock prices. The estimate of financial leverage (Lev) for each year is based on the mean value of the preceding five years. Two such estimates were also constructed: "Relative" and "Absolute." The Relative Lev estimate for a given year is the mean value of the Lev variable across the preceding five years, while the Absolute Lev is given by the 5-year mean value of the "debt" numerator divided by the 5-year mean value of the "equity" denominator. Table 1 presents the full descriptive statistics of the financial leverage ratios, and a full discussion is also provided in Section 5.

\subsubsection{Beta of Debt $\left(\beta_{\mathrm{D}}\right)$}

In contrast to the widespread estimation of equity beta in the literature, the estimation of debt beta is relatively rare. A search of the literature revealed only a few studies, which were also relatively old (see for example: Boquist, Racette, and Schlarbaum [37]; Lanstein, Ronald and Sharpe [38]; and Livington [39]. Reilly and Joehnk [40] estimated the systematic risk of debt based on a sample of 73 industrial and utilities bonds. They reported a mean value of 0.25 and 0.17 for the utilities and industrial sectors, respectively. They also found that in most cases, the difference between the bonds based on their ratings was not significant. Alexander [41] conducted a study on long-term bonds that 
corresponded to Reilly and Joehnk's sample. He reported a mean debt beta of 0.22 and 0.37 for the stock and debt indexes, respectively. He also argued that his results showed that the assumptions of the normality of residuals, the lack of serial correlation, and homoscedasticity were seriously violated when the market portfolio was defined as a debt index. Moreover, he argued that the use of the market model to analyze bonds with any index appears to involve both notable violations of regression assumptions and instances of parameter instability. Thus, any interpretation of studies that entail the analyses of bonds in the market model context must be made with extreme caution. Weinstein [42] examined the systematic risk of corporate bonds from 1962 to 1974 for three different market indexes: the NYSE index, a combined index of bonds and stocks, and only a bond index. He found a mean beta that ranged from 0.028 to 0.301 , depending on which market portfolio was used. Cornell and Green [43] investigated all publicly traded low-grade bond funds from January 1960 to December 1989. During the entire period, the mean beta of high-grade bonds was 0.22 , and 0.42 for low-grade bond funds. However, their results were different when they divided their sample into sub periods. While the mean value was 0.19 and 0.54 for the high and low-grade funds during 1960 to 1976, respectively, the mean value was 0.25 and 0.29 from 1977 through 1989 .

To summarize, the existing studies in the literature point to difficulties associated with estimating debt beta such as the lack of sufficient data, different maturities, different durations, and other features of bonds. Hence, it is not clear which bonds would be best suited to measuring systematic debt risk. Any attempt to estimate the risk of a bond from historical time series data involves a trade-off between the benefits associated with many observations and the cost of non-stationarity, because decreasing durations, for instance, leads to lower volatility over time.

Given the mixed results and econometric issues such as stationarity problems that arise from the different maturities of specific bonds as well as the lack of adequate bond data, we followed Aharon and Yagil $[35,36]$, and estimated the mean value of $\beta_{D}$ using the Bloomberg interface by applying the CAPM (Capital Asset Pricing Model) in each sample year to the iBoxx ETF (Exchange Traded Fund). This bond ETF includes a broad representation of U.S. dollar-denominated high and low yield liquid corporate bonds. The mean value and standard deviation of the ETF betas across the sample years came to 0.3 and 0.063 , respectively. For compatibility purposes, we estimated the debt betas using the same approach used for estimating the equity betas including the employment of the same market index, the NYSE composite index. With regard to the equity betas, we followed the practice in the empirical literature and used an all-equity index for estimating the stock betas. Given this practice, also using the same index for bonds may reduce the bias resulting from the use of an alternative index such as an all-debt index or a debt-and-equity index. Indeed, Weinstein [42] also employed the NYSE index for estimating bond betas, implying that such an approach is not an uncommon practice. To compensate for a possible bias in the beta estimate, however, we used below a range of mean bond betas that may appear consistent with the mean bond beta values reported in the literature, and which very likely may contain the true unobservable mean bond betas. Consistent with the range of mean debt beta values obtained in the literature and reported above, we set the individual bond betas in our sample to be given by the mean bond beta value plus a component that is mainly a function of the individual company's financial leverage. This adjustment procedure is described below. To be consistent with the mean bond betas found in the literature, we used a mean range of $0.1,0.2$, and 0.3 , which may likely contain unobservable mean bond beta. This mean range has been employed for sensitivity purposes and to account for potential measurement errors. As noted in Section 5.3, the main results of the study are essentially similar for these three mean bond beta estimates.

Each mean value is then adjusted separately for each firm to reflect the individual bond beta by incorporating the deviation of the specific company's financial leverage from the entire sample's financial leverage. Consider, for example, the following parameter values: the mean and standard deviation of $\beta_{\mathrm{D}}$ for the entire sample were 0.3 and 0.063 (based on the Bloomberg ETF sample), the mean and standard deviation values for the financial leverage of the entire sample were 1.5 and 0.5 , respectively, and the specific company's financial leverage was 2.5 . The estimate for the specific 
company's $\beta_{\mathrm{D}}$ will be given as follows: $\beta_{\mathrm{D}}=0.3+2 \times 0.063=0.426$, where the $\mathrm{Z}$ score of 2 is given by $(2.5-1.5) / 0.5=2$.

\subsubsection{The Business Systematic Risk ( $\left.\beta_{\mathrm{U}}\right)$}

The standard approach in the literature as initially suggested by Hamada (4) Rubinstein (5), and Conine and Tomarkin [44] is to estimate the unlevered equity's beta $\left(\beta_{U}\right)$ from the observable equity beta $\left(\beta_{\mathrm{E}}\right)$, incorporating relevant adjustments that depend on the market imperfections considered (e.g., Bernardo, Chowdhry and Goyal [45], Cooper and Nyborg [46,47]. Another approach is to simply use zero leverage firms. However, Doshi et al. [48] stated that using such procedures may end in a relatively small sample and lead to a severe selection bias.

The estimations of Models $(1 b)-(4 b)$ require an estimate for $\beta_{U}$. Accordingly, the estimate for $\beta_{U}$ in Model (1b) is based on Model (1a). Similarly, the estimate for $\beta_{U}$ in Model (2b) is based on Model (2a), and the same applies to Models (3b) and (4b). The $\beta_{U}$ estimate for each year is based on the preceding 5-year period. It might be worth noting that the GICS (Global Industry Classification Standard) in COMPUSTAT for the industrial sector is considered here as roughly reflecting a similar level of business risk.

\subsubsection{Corporate and Personal Tax Rates $\left(\mathrm{T}_{\mathrm{C}}\right.$ and $\left.\mathrm{T}_{\mathrm{E}}\right)$}

Testing some of the models in this research requires estimates of the corporate tax rate $\left(\mathrm{T}_{\mathrm{C}}\right)$ and the personal tax rates for both equity holders $\left(\mathrm{T}_{\mathrm{E}}\right)$ and debt holders $\left(\mathrm{T}_{\mathrm{D}}\right)$. Most proxies for the corporate tax rate are based on the ratio of the total income tax expense to pre-tax income (see for example: Arena and Roper [49]; Dyreng, Hanlon and Maydew [50]; Fan, Titman and Twite [51], or by assuming a constant corporate tax rate (Kemsley and Nissim [52]; DeAngelo, DeAngelo and Whited [53]. Following the first set of studies, we used the total tax expense divided by pretax income as a proxy for the corporate tax variable. The estimate of the corporate tax rate $\left(T_{C}\right)$ for each year was based on the mean value of the preceding five years. As in the case of the other variables estimated, to account for potential measurement errors and for the sake of robustness analysis, we constructed two estimates for Tc: "Relative" and "Absolute." The Relative $\mathrm{T}_{\mathrm{C}}$ estimate for a given year is the mean value of the $T_{C}$ variable across the preceding five years. The Absolute $\mathrm{T}_{\mathrm{C}}$ is given by the 5-year mean value of the firm's total tax expense divided by the 5-year mean value of the firm's taxable income (the annual means of the corporate tax rate variable are presented in Table 2). Butler, Mohr, and Simonds [54] set the outliers of corporate tax rates to $40 \%$ because such rates are likely to be associated with nonrecurring or unusual items. They stated that this procedure is necessary for approximately $15 \%$ of the sample firms. We followed this procedure for approximately $12 \%$ of the sample firms. Corporate tax rate values exceeding $60 \%$ were set to the mean value plus two standard deviations, while tax rate values lower than $20 \%$ were set to the mean value minus two standard deviations.

The taxes ratio $\left(T_{R}\right)$ is defined here as: $T_{R}=\left[\left(1-T_{E}\right) /\left(1-T_{D}\right)\right]$, where $T_{D}$ is the tax rate for debt holders, and $\mathrm{T}_{\mathrm{E}}$ is the tax rate applicable to equity holders. $\mathrm{T}_{\mathrm{E}}$ is a weighted-average tax rate on dividend and capital gains income. In other words, it is the tax rate on dividend $\left(T_{d}\right)$ and capital gains $\left(T_{c g}\right)$ income expressed as: $\mathrm{T}_{\mathrm{E}}=\left[d \cdot T_{d}+(1-\mathrm{d}) \cdot \alpha \cdot T_{c g}\right]$, where $d$ is the ratio of the most recent year's net income that was paid out in dividends divided by the mean value of the total earnings over the prior three years. Accordingly, $(1-\mathrm{d})$ is the retention ratio. Following the procedure devised by Dhaliwal, Heitzman, and Li [55], we winsorized $d$ at zero and one. $T_{d}$ is the personal tax rate on dividend income, which was set equal to the values of $\mathrm{T}_{\mathrm{D}}$ for the years prior to 2003 , and $15 \%$ thereafter. $T_{\text {cg }}$ is set equal to the top statutory tax rate on long-term capital gains income, which equaled 20\% for 1998 through 2002, and $15 \%$ thereafter. $\alpha$ is the benefit of capital gains deferral. Following Dhaliwal, Heitzman, and Li [55], van Binsbergen, Graham and Yang [56], and Graham [57], we assumed that $\alpha=0.25$. Following Dhaliwal, Heitzman, and Li [55], $\mathrm{T}_{\mathrm{D}}$ was measured as the highest statutory tax rate on interest income, which was 39.6\% for 1998 through 2000, 38.6\% for 2001 through 2002, and 35\% thereafter. 
Table 2. Descriptive statistics of the tax estimates.

\begin{tabular}{|c|c|c|c|c|c|c|}
\hline \multicolumn{7}{|c|}{ Panel A } \\
\hline $\operatorname{Rel} \mathrm{T}_{\mathrm{C}}$ & 2007 & 2006 & 2005 & 2004 & 2003 & Mean \\
\hline Mean & 0.345 & 0.350 & 0.355 & 0.364 & 0.374 & 0.358 \\
\hline Med & 0.344 & 0.342 & 0.353 & 0.359 & 0.373 & 0.354 \\
\hline SD & 0.073 & 0.078 & 0.083 & 0.085 & 0.073 & 0.078 \\
\hline $\mathrm{CV}$ & 0.211 & 0.223 & 0.235 & 0.232 & 0.195 & 0.219 \\
\hline Min & 0.202 & 0.203 & 0.207 & 0.201 & 0.210 & 0.205 \\
\hline Max & 0.562 & 0.567 & 0.569 & 0.595 & 0.567 & 0.572 \\
\hline \multicolumn{7}{|c|}{ Panel B } \\
\hline$d$ & 2007 & 2006 & 2005 & 2004 & 2003 & Mean \\
\hline Mean & 0.174 & 0.184 & 0.205 & 0.227 & 0.236 & 0.205 \\
\hline Med & 0.162 & 0.164 & 0.200 & 0.182 & 0.140 & 0.170 \\
\hline SD & 0.177 & 0.199 & 0.211 & 0.250 & 0.274 & 0.222 \\
\hline $\mathrm{CV}$ & 1.018 & 1.082 & 1.028 & 1.101 & 1.161 & 1.078 \\
\hline Min & 0.000 & 0.000 & 0.000 & 0.000 & 0.000 & 0.000 \\
\hline Max & 1.000 & 1.000 & 1.000 & 1.000 & 1.000 & 1.000 \\
\hline \multicolumn{7}{|l|}{$T_{E}$} \\
\hline Mean & 0.057 & 0.058 & 0.061 & 0.063 & 0.064 & 0.061 \\
\hline Med & 0.056 & 0.056 & 0.060 & 0.058 & 0.053 & 0.057 \\
\hline SD & 0.020 & 0.022 & 0.024 & 0.028 & 0.031 & 0.025 \\
\hline $\mathrm{CV}$ & 0.349 & 0.385 & 0.391 & 0.446 & 0.482 & 0.411 \\
\hline Min & 0.038 & 0.038 & 0.038 & 0.038 & 0.038 & 0.038 \\
\hline Max & 0.150 & 0.150 & 0.150 & 0.150 & 0.150 & 0.150 \\
\hline \multicolumn{7}{|l|}{$T_{R}$} \\
\hline Mean & 1.451 & 1.449 & 1.445 & 1.441 & 1.440 & 1.445 \\
\hline Med & 1.453 & 1.452 & 1.446 & 1.449 & 1.456 & 1.451 \\
\hline SD & 0.031 & 0.034 & 0.036 & 0.043 & 0.047 & 0.038 \\
\hline $\mathrm{CV}$ & 0.021 & 0.024 & 0.025 & 0.030 & 0.033 & 0.027 \\
\hline Min & 1.308 & 1.308 & 1.308 & 1.308 & 1.308 & 1.308 \\
\hline Max & 1.481 & 1.481 & 1.481 & 1.481 & 1.481 & 1.481 \\
\hline
\end{tabular}

The statistics for the corporate tax rates ( $\mathrm{T}_{\mathrm{C}}$, both Relative and Absolute), the dividend payout ratio (d) next to the personal tax rate $\left(T_{E}\right)$, and the taxes ratio $\left(T_{R}\right)$ are presented in Table 3 , in panels $A$, $B$, and $C$. The right hand side of each panel summarizes the overall statistics for the entire sample time period. 
Table 3. Regression results: all firms.

\begin{tabular}{|c|c|c|c|c|c|c|c|c|c|c|}
\hline \multicolumn{11}{|c|}{ Risk Free Debt Models } \\
\hline & $\operatorname{Lev}_{2}(\mathrm{Mv})$ Rel & & 2007 & 2006 & 2005 & 2004 & 2003 & Mean & Min & Max \\
\hline \multirow{3}{*}{ Model (1a) } & \multirow{3}{*}{$\begin{array}{l}\text { Perfect capital } \\
\text { market }\end{array}$} & Intercept & 1.130 & 0.929 & 0.933 & 0.860 & 0.872 & 0.945 & 0.860 & 1.130 \\
\hline & & Slope & 0.444 & 0.486 & 0.415 & 0.336 & 0.225 & 0.381 & 0.225 & 0.486 \\
\hline & & $\mathrm{R}^{2}$ & 0.132 & 0.247 & 0.195 & 0.152 & 0.070 & 0.159 & 0.070 & 0.247 \\
\hline \multicolumn{2}{|c|}{$\mathrm{HO}: \gamma_{1}=0$} & Slope Sig & 0.000 & 0.000 & 0.000 & 0.000 & 0.000 & 0.000 & 0.000 & 0.000 \\
\hline \multirow{3}{*}{ Model (2a) } & \multirow{3}{*}{ Corporate taxes } & Intercept & 1.135 & 0.931 & 0.928 & 0.863 & 0.865 & 0.944 & 0.863 & 1.135 \\
\hline & & Slope & 0.644 & 0.720 & 0.651 & 0.507 & 0.378 & 0.580 & 0.378 & 0.720 \\
\hline & & $\mathrm{R}^{2}$ & 0.134 & 0.247 & 0.192 & 0.144 & 0.074 & 0.158 & 0.074 & 0.247 \\
\hline \multicolumn{2}{|c|}{$\mathrm{HO}: \gamma_{1}=0$} & Slope Sig & 0.000 & 0.000 & 0.000 & 0.000 & 0.000 & 0.000 & 0.000 & 0.000 \\
\hline \multirow{3}{*}{ Model (3a) } & \multirow{3}{*}{$\begin{array}{l}\text { Corporate and } \\
\text { Personal taxes }\end{array}$} & Intercept & 1.135 & 0.932 & 0.929 & 0.864 & 0.866 & 0.945 & 0.864 & 1.135 \\
\hline & & Slope & 0.439 & 0.490 & 0.445 & 0.347 & 0.260 & 0.396 & 0.260 & 0.490 \\
\hline & & $\mathrm{R}^{2}$ & 0.136 & 0.249 & 0.194 & 0.145 & 0.074 & 0.160 & 0.074 & 0.249 \\
\hline \multicolumn{2}{|c|}{ HO: $\gamma_{1}=0$} & Slope Sig & 0.000 & 0.000 & 0.000 & 0.000 & 0.000 & 0.000 & 0.000 & 0.000 \\
\hline \multicolumn{11}{|c|}{ Risky Debt Models } \\
\hline \multirow{3}{*}{ Model (1b) } & \multirow{3}{*}{$\begin{array}{l}\text { Perfect capital } \\
\text { market }\end{array}$} & Intercept & 1.155 & 0.935 & 0.913 & 0.826 & 0.825 & 0.931 & 0.825 & 1.155 \\
\hline & & Slope & 0.671 & 0.826 & 0.809 & 0.681 & 0.543 & 0.706 & 0.543 & 0.826 \\
\hline & & $R^{2}$ & 0.054 & 0.128 & 0.162 & 0.146 & 0.103 & 0.118 & 0.054 & 0.162 \\
\hline \multicolumn{2}{|c|}{$\mathrm{HO}: \gamma_{1}=0$} & Slope Sig & 0.002 & 0.000 & 0.000 & 0.000 & 0.000 & 0.000 & 0.000 & 0.002 \\
\hline \multicolumn{2}{|c|}{ HO: $\gamma_{0}=\beta_{U}^{*}$} & Sig & 0.048 & 0.291 & 0.183 & 0.259 & 0.106 & 0.177 & 0.048 & 0.291 \\
\hline \multicolumn{2}{|c|}{ HO: $\gamma_{1}=1$} & Sig & 0.523 & 0.892 & 0.606 & 0.289 & 0.030 & 0.468 & 0.03 & 0.892 \\
\hline \multirow{3}{*}{ Model (2b) } & \multirow{3}{*}{ Corporate taxes } & Intercept & 1.119 & 0.899 & 0.910 & 0.836 & 0.819 & 0.917 & 0.819 & 1.119 \\
\hline & & Slope & 1.086 & 1.273 & 1.130 & 0.900 & 0.806 & 1.039 & 0.806 & 1.273 \\
\hline & & $\mathrm{R}^{2}$ & 0.095 & 0.200 & 0.173 & 0.147 & 0.114 & 0.146 & 0.095 & 0.200 \\
\hline \multicolumn{2}{|c|}{ HO: $\gamma_{1}=0$} & Slope Sig & 0.000 & 0.000 & 0.000 & 0.000 & 0.000 & 0.000 & 0.000 & 0.000 \\
\hline \multicolumn{2}{|c|}{ HO: $\gamma_{0}=\beta_{\mathrm{U}}^{*}$} & Sig & 0.074 & 0.390 & 0.154 & 0.444 & 0.366 & 0.286 & 0.074 & 0.444 \\
\hline \multicolumn{2}{|c|}{ HO: $\gamma_{1}=1$} & Sig & 0.752 & 0.749 & 0.296 & 0.298 & 0.438 & 0.507 & 0.296 & 0.752 \\
\hline \multirow{3}{*}{ Model (3b) } & \multirow{3}{*}{$\begin{array}{l}\text { Corporate and } \\
\text { Personal taxes }\end{array}$} & Intercept & 1.120 & 0.899 & 0.908 & 0.831 & 0.813 & 0.914 & 0.813 & 1.120 \\
\hline & & Slope & 0.818 & 0.966 & 0.863 & 0.696 & 0.631 & 0.795 & 0.631 & 0.966 \\
\hline & & $R^{2}$ & 0.090 & 0.192 & 0.170 & 0.148 & 0.117 & 0.143 & 0.090 & 0.192 \\
\hline \multicolumn{2}{|c|}{ HO: $\gamma_{1}=0$} & Slope Sig & 0.000 & 0.000 & 0.000 & 0.000 & 0.000 & 0.000 & 0.000 & 0.000 \\
\hline $\mathrm{HO}$ & $\gamma_{0}=\beta_{\mathrm{U}}^{*}$ & Sig & 0.090 & 0.499 & 0.265 & 0.269 & 0.243 & 0.273 & 0.09 & 0.499 \\
\hline & $\gamma_{1}=1$ & Sig & 0.750 & 0.515 & 0.907 & 0.357 & 0.178 & 0.541 & 0.178 & 0.907 \\
\hline & Corporate and & Intercept & 1.158 & 0.944 & 0.914 & 0.838 & 0.820 & 0.935 & 0.820 & 1.158 \\
\hline Model (4b) & Personal taxes, & Slope & 0.928 & 1.121 & 1.062 & 0.775 & 0.517 & 0.881 & 0.517 & 1.121 \\
\hline & ste & $\mathrm{R}^{2}$ & 0.051 & 0.127 & 0.191 & 0.218 & 0.209 & 0.159 & 0.051 & 0.218 \\
\hline & $\gamma_{1}=0$ & Slope Sig & 0.002 & 0.000 & 0.000 & 0.000 & 0.000 & 0.000 & 0.000 & 0.002 \\
\hline $\mathrm{HO}$ & $\gamma_{0}=\beta_{\mathrm{U}}^{*}$ & Sig & 0.057 & 0.326 & 0.342 & 0.334 & 0.256 & 0.263 & 0.057 & 0.342 \\
\hline & $\gamma_{1}=1$ & Sig & 0.426 & 0.976 & 0.382 & 0.357 & 0.326 & 0.493 & 0.326 & 0.976 \\
\hline
\end{tabular}

\subsubsection{Bankruptcy Costs (q)}

Recall that Model (4b) of the relationship between beta and leverage incorporates risky debt and bankruptcy costs. The bankruptcy costs factor (q) is given by the expected value of bankruptcy divided by the value of the debt. Based on the empirical findings of bankruptcy in the literature, an attempt was made to estimate the bankruptcy factor (q) in Model (4b).

The literature establishes that financial leverage can increase the probability of insolvency and the risk of claimholders, and hence the expected value of bankruptcy costs. The latter consists of both the direct and indirect costs of bankruptcy. Most of the empirical studies in the literature have focused on 
measuring direct costs because indirect costs are not directly observable. Thus, the literature offers mixed results concerning the value of bankruptcy costs, perhaps also due to variations in the sample sizes and sample periods.

Warner [58] estimated the direct bankruptcy costs of 11 US railroad companies that were in bankruptcy proceedings from 1933 to 1955 . He found that these costs averaged $1 \%$ of the market value of the firm seven years before entering into Chapter 11 and rose to $4 \%$ one year prior to bankruptcy. In his 1990 study of 37 industrial firms between 1979 and 1986, Weiss [59] found that on average, the direct costs were $3.1 \%$ of the book value of the debt and market value of the firm's equity. Miller [60] argued that the direct cumulative bankruptcy costs average only $5.3 \%$ of the value of the firm and $1.7 \%$ for the largest firms. Miller also suggested that the total loss of the market value 84 months prior to the bankruptcy date equaled $1.3 \%$ of the firm's value. Altman [61] estimated the total bankruptcy costs (both direct and indirect) as $16.7 \%$ of a firm's value in the year in which the firm becomes insolvent, $11.2 \%$ of the firm's value one year prior to the bankruptcy, $11.7 \%$ of the firm's value two years prior to the bankruptcy, and $12.4 \%$ of the firm's value three years prior to the bankruptcy. Andrade and Kaplan [62] pointed out that many previous studies that examined the indirect costs of financial distress failed to distinguish financial distress from economic distress. By examining a sample of 31 highly leveraged transactions, their results showed that the indirect costs of financial distress were $10 \%$ to $23 \%$ of a firm's value. Lubben [63] used a sample of 22 firms from 1994 and calculated that the cost of legal counsel in Chapter 11 bankruptcy was on average about $1.8 \%$ of the distressed firm's total assets, and could be as high as $5 \%$.

In their study of firms that entered into Chapter 7 or Chapter 11 proceedings, Bris, Welch, and Zhu [64] found a range of estimates from $2 \%$ to $20 \%$ to the firm's assets, but advised caution when using these results. They argued that their measures were sensitive to the procedure, particularly to the denominator (how the assets are measured). More specifically, they advise theorists not to claim either uniformly low or uniformly high bankruptcy costs, but rather to recognize that bankruptcy costs are modest in some firms and large in others. Garlappi and Yan [65] provided a measure of expected default probability (EDF). A firm's EDF measure represents an assessment of the likelihood of default for that firm within a year. They reported an average EDF measure of $3.30 \%$. They also stated that $75 \%$ of firms had a default probability of less than $3.5 \%$, and around $5 \%$ of the firms were assigned an EDF score of 20\%. Finally, Hortaçsu, Matvos, Syverson, and Venkataraman [66] presented a mechanism through which decisions on a firm's financial structure create indirect costs of financial distress in the auto market. Using data about wholesale auction price and credit default swap spreads (CDS) for used cars sold, they found that a 1000-basis-point movement in CDS spreads caused a price reduction of $\$ 68$, about $0.5 \%$ of the average sales price in their sample.

Given the mixed results in the literature, and the potential of measurement errors in estimating bankruptcy costs, we used a wide set of four alternative measures for the bankruptcy costs factor (q) that should cover the true value of the $q$ factor. Thus, Model (4b) will be tested using four possible mean values of $\mathrm{q}: 3 \%, 7 \%, 11 \%$, and $15 \%$ of the firm's debt. Recall that $\mathrm{q}=\mathrm{C} / \mathrm{D}$, where $\mathrm{C}$ is the expected value of the bankruptcy costs, and $D$ is the value of the debt. In determining this set, we already considered that $\mathrm{q}$ is in terms of the debt rather than the total value of the firm.

\section{Empirical Findings}

\subsection{Descriptive Statistics}

The focus of this study was to test the theoretical relationship between the beta and financial leverage of the firm. Table 1 presents the descriptive statistics of the beta and financial leverage estimates, and Table 2 shows the descriptive statistics for the tax rate estimates.

Following Aharon and Yagil [35,36], the beta and financial leverage estimates were computed for each year in the overall sample time period. The statistics were computed across 182 companies in the 
NYSE industrial sector. A detailed explanation for the construction of the key variables is given in Sections 4.2.1 and 4.2.2

The top of Table 1 presents the descriptive statistics for the $\beta_{\mathrm{E}}$ estimates, which are the mean, median (Med), standard deviation (SD), coefficient of variation (CV), minimum (Min), and maximum (Max) values. The last row reports the overall mean value for the sample years. For example, the mean value of $\beta_{\mathrm{E}}$ in 2006 was 1.15 , and the overall mean value across the years was 1.13 . As Table 1 demonstrates, the analysis across the sample years revealed that the mean value of the equity's risk estimate in 2007 was the highest. This result is also evident in the corresponding median values. Apparently, the outbreak of the subprime crisis beginning in the middle of 2007 is related to the increase in market risk.

The bottom of Table 1 presents the descriptive statistics of the Relative leverage estimates. The corresponding Absolute estimates are not reported here, because they were very similar to the Relative estimates (the various leverage estimates are defined in both Section 4 and the tables). It is clear that both the mean and median book estimates were higher than their corresponding estimates in market values. For example, in 2006, the Relative mean value of $\operatorname{Lev}_{1}$ (which is the book value) was 0.81 , while the mean value of $\operatorname{Lev}_{2}$ (which is the market value) equaled 0.46 . Similarly, the $\mathrm{Lev}_{3}$ estimate equaled 1.61 , and the corresponding market estimate $\left(\operatorname{Lev}_{4}\right)$ was 0.93 . Similar results were obtained for the mean value of the Absolute measures of leverage and with respect to the various median leverage values.

The fourth column in each year in Table 1 presents the variation in the leverage estimates. As expected, and as demonstrated by the coefficient of variation $(\mathrm{CV})$, the market estimates $\left(\mathrm{Lev}_{2}\right.$ and $\left.\mathrm{Lev}_{4}\right)$ were more volatile than their corresponding book estimates $\left(\operatorname{Lev}_{1}\right.$ and $\left.\operatorname{Lev}_{3}\right)$. For example, the overall mean value of CV was 1.41 and 1.02 for the Relative measures of $\operatorname{Lev}_{1}$ and $\operatorname{Lev}_{2}$, and 1.51 and 1.15 for $\mathrm{Lev}_{3}$ and $\mathrm{Lev}_{4}$, respectively. The Absolute measures of leverage yielded similar findings. Analysis across the sample years in Table 1 revealed that the mean value of financial leverage estimates in 2007 was lower than other test years. Presumably, the outbreak of the subprime crisis in the middle of this year had an impact on the debt value.

Table 2 presents a summary of the descriptive statistics for the corporate tax rate variable $\left(T_{C}\right)$, the payout ratio $(d)$, the personal tax rate $\left(\mathrm{T}_{\mathrm{E}}\right)$, and the descriptive statistics for the taxes ratio $\left(\mathrm{T}_{\mathrm{R}}\right)$ given by $\left(1-\mathrm{T}_{\mathrm{E}} / 1-\mathrm{T}_{\mathrm{D}}\right)$.

Panel A reports the corporate tax estimates for each year in the overall sample time period. The statistics were computed across 182 companies in the industrial sector. Similarly to Aharon and Yagil [1,2], two estimates were constructed: Relative and Absolute $\mathrm{T}_{\mathrm{C}}$. A detailed explanation for the construction of the tax estimates is given in Section 4.2.5.

Panel A presents the descriptive statistics of the Relative corporate tax rate estimates. For example, the Relative mean value of $\mathrm{T}_{\mathrm{C}}$ in 2007 was 0.345 , while the median value equaled 0.344 . Similarly, the corresponding Absolute estimate equaled 0.342, and the median value equaled 0.341 (though not reported here). Overall, the Relative method of measurement, rather than the Absolute measure yielded similar values of $\mathrm{T}_{\mathrm{C}}$.

The top of Panel B presents the descriptive statistics of the dividend payout ratio $(d)$, which serves as a key variable in the measurement of the personal tax rate $\left(\mathrm{T}_{\mathrm{E}}\right)$. The mean value of the payout ratio (d) in 2007 was 0.174 , while the median value equaled 0.162 . In addition, the mean value across the five sample years was 0.205 with a Min-Max range of 0.174 to 0.236 . Finally, the bottom of Panel B reports the $T_{E}$ estimates for the sample years. The mean value of $T_{E}$ in 2007 , for example, was 0.057 with a standard deviation of 0.02 .

The taxes ratio $\left[T_{R}=\left(1-T_{E}\right) /\left(1-T_{D}\right)\right]$, associated with debt, represents the relative tax disadvantage for individual investors of receiving a dollar of interest income versus a dollar of equity income. Larger values for the personal tax penalty imply that equity financing is more attractive, as potential stockholders will require a lower pretax return relative to potential lenders. Panel B shows that the penalty is quite steady, as indicated by both the mean and median values across the sample years. For example, the mean value of $\mathrm{T}_{\mathrm{R}}$ varied only from 1.440 to 1.451 through the sample years. 
Dhaliwal et al. [55] reported similar results to those obtained here. For example, their mean value of $\mathrm{T}_{\mathrm{R}}$ was 1.428 , which is quite similar to the 1.445 reported here.

\subsection{Findings for the Risk Free Debt Models}

As described above, we used a number of different estimates for the variables including financial leverage, corporate tax rate, personal tax rate, debt beta, and bankruptcy costs, yielding numerous results from the regression equations. The tables present the results for a given set of variable estimates, while reference to the other variable estimates is made in the text itself. It should also be noted that the findings were similar for a wide range of variable estimates. We will begin with the estimation results of the risk free debt models described in Models (1a)-(3a) and proceed later with the risky debt models described in Models (1b)-(4b).

\subsubsection{The Findings for the Perfect Capital Markets Case: Model (1a)}

Table 3 presents only the results of the estimated regressions [Models (1a)-(4b)] according to Relative $\mathrm{Lev}_{2}$. We obtained similar results (not included in Table 3) when the financial leverage was based Lev $1, \operatorname{Lev}_{3}$ or $\operatorname{Lev}_{4}$.

The table presents the following statistics: the intercept, slope, $\mathrm{R}^{2}$, and the significance of the slope (the significance level of the intercept is not reported here, because it was significant at the $1 \%$ level in all cases). The main result that emerges from Table 3, and perhaps the most important one, is that as financial theory dictates, there is a positive relationship between risk and leverage. This result holds for each year in the sample and for all four leverage estimates. All of the additional tests conducted (though not reported here) using other Lev estimates (that is, using LTD + CL in the numerator of the financial leverage ratio) were also significant at the $1 \%$ level. The significance of the results also holds, regardless of whether the Absolute or Relative method is employed. However, the results also indicate that the relationship between risk and leverage is stronger when using market measures of financial leverage rather than book measures. Finally, we obtained similar results not included in Table 3 when the financial leverage was based on the total debt $\left(\operatorname{Lev}_{3}, \operatorname{Lev}_{4}\right)$, rather than the long-term debt (Lev $\mathrm{Lev}_{2}$ ). To obtain an indication about the results for an abnormal year, we tested the beta-leverage relationship for 2002. The findings imply that even for such an abnormal year, the relationship between beta and leverage was significantly positive. Note that the relationship between beta and leverage (as reported by $\mathrm{R}^{2}$ ) was weaker in 2007 than in any other sample year, possibly due to the outbreak of the subprime crisis in July 2007.

A quick look also reveals that $\gamma_{1}$ was lower than $\gamma_{0}$ in each year, supporting the idea that $\gamma_{1}$ might be taking other market imperfections into account. As will be discussed later in Section 5.4, in most cases, the differences between $\left[\gamma_{0}-\beta_{U}^{*}\right]$ and $\left[\gamma_{1}-\beta_{U}{ }^{*}\right]$ were statistically significant. This result implies that while the relationship between beta and financial leverage is positive, the observed gap between $\gamma_{0}$ and $\gamma_{1}$ is possibly due to other market imperfections not considered here. The gap is evident in each of the sample years and for all financial leverage estimates employed. For example, for $\mathrm{Lev}_{2}$ reported in Table 3, the mean values of $\gamma_{0}$ and $\gamma_{1}$ across all sample years were 0.945 and 0.381 , respectively. As noted earlier, a possible explanation for this substantial difference between $\gamma_{0}$ and $\gamma_{1}$ may stem from the non-incorporation of capital market imperfections

Another interesting result emerges from the comparison between $\beta_{\mathrm{E}}$ and $\gamma_{0}$. Given that the equity beta $\left(\beta_{\mathrm{E}}\right)$ reflects both business and financial risk, it should be higher than $\gamma_{0}$, which should reflect the business risk only. The various tests indeed indicate that $\beta_{\mathrm{E}}>\gamma_{0}$. For example, the mean value of $\beta_{\mathrm{E}}$ in 2006 was 1.15 (see the second line in Table 1), while the value of $\gamma_{0}$ was 0.929 . This result holds for all financial measures and across all the sample years.

\subsubsection{The Findings for the Corporate Tax Case: Model (2a)}

Table 3 presents the results, among others, of the estimated regression of Model (2a) using the Absolute $\mathrm{T}_{\mathrm{C}}$ measure and the Relative $\mathrm{Lev}_{2}$ estimate. However, the results were very similar when the 
Relative rather than the Absolute measure was employed, and when the financial leverage was based on $\operatorname{Lev}_{1}, \mathrm{Lev}_{3}$, or $\mathrm{Lev}_{4}$. As discussed in Section 4, we estimated the corporate tax rate $\left(\mathrm{T}_{\mathrm{C}}\right)$, like the financial leverage, using both Relative and Absolute methods.

The estimated regression equation corresponding to Model (2a) is given by Equation (10), where the dependent variable is $\beta_{\mathrm{E}}$, while the explanatory variable is $\left[\left(1-\mathrm{T}_{\mathrm{C}}\right) \mathrm{L}\right]$, and by the null hypothesis $\left(\mathrm{H}_{0}\right): \gamma_{0}=\beta_{\mathrm{U}}$, and, $\gamma_{1}=\beta_{\mathrm{U}}$. The main estimation results of the corporate tax case [Model (2a)] in Table 3 were similar to those of the perfect capital markets case [Model (1a)]. Thus, all of the tests conducted here showed that both $\gamma_{0}$ and $\gamma_{1}$ were significant, and that as financial theory dictates, there is a positive relationship between beta and leverage. Note, too, that due to the incorporation of the corporate tax factor that exists in reality, the gap between $\gamma_{0}$ and $\gamma_{1}$ was relatively lower in Model (2a) than in Model (1a). For example, looking at the mean value of the intercept and slope at the end of the first two lines of Table 3, the gap between $\gamma_{0}$ and $\gamma_{1}$ across all five years was 0.364 (0.944-0.580) for Model (2a) compared with the corresponding gap of 0.564 (0.945-0.381) for Model (1a). This result may be related to the inclusion of the corporate tax factor in Model (2a). As in the preceding case, here too, the results for an abnormal year such as 2002 were generally similar to those reported above for the sample years. Once again, 2007 still remains a year with possibly a higher degree of business risk, as implied by the highest mean value of $\gamma_{0}$ compared with the rest of the sample years.

\subsubsection{The Findings for the Combined Tax Case: Model (3a)}

Model (3a) presents the situation when personal taxes exist. Its corresponding regression equation is given by Equation (6), where the explanatory variable is [TL], where $T=\left(1-T_{C}\right)\left(1-T_{E}\right) /\left(1-T_{D}\right)$, $\mathrm{L}$ is the financial leverage variable, and by $\mathrm{H}_{0}: \gamma_{0}=\beta_{\mathrm{U}}$, and $\gamma_{1}=\beta_{\mathrm{U}}$. The estimation results of the regression equation presented in Table 3 show that the relationship between beta and leverage for Model (3a) were generally similar to those for Model (2a), and Model (1a). However, the gap between $\gamma_{0}$ and $\gamma_{1}$ corresponds to the magnitude of the explanatory variable underlying these three equations, as demonstrated in Models (1a)-(3a). As indicated by the corresponding regression Equations (7), (11), and (6), respectively, are as follows: [1], [(1- $\left.\left.\mathrm{T}_{\mathrm{C}}\right) \mathrm{L}\right]$, and [TL] for Equations (1a), (2a), and (3a), respectively, where $(1-\mathrm{TC})<\mathrm{T}<1$. Accordingly, the $\left[\gamma_{0}-\gamma_{1}\right]$ gap should be highest for Model (1a) and lowest for Model (2a). An examination of the $\left[\gamma_{0}-\gamma_{1}\right]$ gap in Table 3 verifies this result. Specifically, the mean gap across all sample years was equal to 0.564 (0.945-0.381), $0.364(0.944-0.580)$, and $0.549(0.945-0.396)$. Similar findings were obtained for the abnormal year 2002. The gap for the Absolute Lev1 was equal to 0.73 (0.843-0.113), 0.646 (0.837-0.191), and 0.712 (0.840-0.128) for Models (1a)-(3a), respectively. These results are consistent with capital structure theory. While the impact of corporate taxes on the value of the firm was positive, the impact of the personal tax differential $\left(\mathrm{T}_{\mathrm{D}}-\right.$ $\mathrm{T}_{\mathrm{E}}$ ) was negative. Similarly, when personal taxes are present, the increase in the beta of the equity was lower when compared to the case of corporate taxes only. The reported results so far are for the case of risk free debt, which as discussed above, implies that the null hypothesis is $\gamma_{0}=\beta_{\mathrm{U}}$, and $\gamma_{1}=\beta_{\mathrm{U}}$. However, the null hypothesis is different when debt is risky, which is the case we examine next.

\subsection{Findings for the Risky Debt Models}

In the following section, we discuss the results for the risky debt models, Models (1b)-(4b). As discussed earlier, we seek to fill the existing gap in the literature and determine which of the models outlined earlier most closely approximates the situation in the real world. Hence, we turn now to testing how closely the estimated intercept and slope measures found here are to those implied in the theoretical models. For example, Model ( $3 b)$ tests the impact of both corporate and personal taxes when debt is risky. Thus, comparing the observed intercept and slope (that is, $\gamma_{0}$ and $\gamma_{1}$ ) to the theoretical values (expressed here as $\gamma_{0}{ }^{*}$ and $\gamma_{1}{ }^{*}$ ) will hopefully clarify the relationship between beta and leverage.

Generally, we expect that the models that include expressions of risky debt such as Models (1b)-(4b) will better approximate the real world than those such as Models (1a)-(3a) that are risk free. 
Table 3 presents the results of the estimated regressions of Models (1b)-(4b), all of which yield significantly positive relationships. Also, given the large scale of the tests conducted here, Table 3 reports the results for a given set of the Absolute $\mathrm{T}_{\mathrm{C}}$ measure when $\beta_{\mathrm{D}}=0.1$ and $\mathrm{q}=7 \%$ for the estimation of Model (4b). Using other estimates in the framework of our robustness tests (that is, the Relative $\mathrm{T}_{C}$ measure, other debt betas, $\mathrm{Lev}_{1}, \mathrm{Lev}_{3}$, and $\mathrm{Lev}_{4}$ financial leverage estimates, and different bankruptcy measures) led to similar results in most cases, so we do not report them here. However, in Table 4, we do present the comparison tests obtained when $\beta_{\mathrm{D}}$ is 0.2 and 0.3 for all of the risky models including Models $(1 b)-(3 b)$.

Table 4. Differences between Theoretical Estimates and Observed Parameters.

\begin{tabular}{|c|c|c|c|c|c|c|c|c|c|c|c|}
\hline & & \multicolumn{2}{|c|}{2007} & \multicolumn{2}{|c|}{2006} & \multicolumn{2}{|c|}{2005} & \multicolumn{2}{|c|}{2004} & \multicolumn{2}{|c|}{2003} \\
\hline & & \multicolumn{10}{|c|}{ Risk Free Debt Models HO: $\gamma_{0}{ }^{*}=\beta_{U}{ }^{*} ; \gamma_{1}^{*}=\beta_{U}{ }^{*}$} \\
\hline & Model & $\gamma_{0}-\beta_{U}{ }^{*}$ & $\gamma_{1}-\beta_{U}^{*}$ & $\gamma_{0}-\beta_{U}^{*}$ & $\gamma_{1}-\beta_{U} *$ & $\gamma_{0}-\beta_{U} *$ & $\gamma_{1}-\beta_{U} *$ & $\gamma_{0}-\beta_{U} *$ & $\gamma_{1}-\beta_{U} *$ & $\gamma_{0}-\beta_{U} *$ & $\gamma_{1}-\beta_{U}$ * \\
\hline & $1 \mathbf{a}$ & $0.194 *$ & $-0.496^{*}$ & 0.141 * & $-0.302 *$ & $0.178 *$ & $-0.340 *$ & $0.191 *$ & -0.333 * & 0.237 * & -0.410 * \\
\hline $\operatorname{Rel} \mathrm{T}_{\mathrm{C}}$ & $2 a$ & 0.093 & $-0.368^{*}$ & 0.043 & -0.133 & 0.082 & $-0.237^{*}$ & 0.064 & -0.160 & 0.103 & $-0.282 *$ \\
\hline$A b s \mathrm{~T}_{\mathrm{C}}$ & $2 a$ & 0.098 & $-0.393 *$ & 0.048 & $-0.232 *$ & 0.074 & $-0.203 *$ & $0.099 *$ & -0.257 * & $0.129 *$ & $-0.358^{*}$ \\
\hline $\operatorname{Rel} \mathrm{T}_{\mathrm{C}}$ & $3 a$ & $0.182 *$ & $-0.491 *$ & $0.127^{*}$ & $-0.289 *$ & $0.168^{*}$ & $-0.348^{*}$ & $0.145^{*}$ & $-0.271^{*}$ & 0.180 * & -0.343 * \\
\hline$A b s \mathrm{~T}_{\mathrm{C}}$ & $3 a$ & $0.187^{*}$ & $-0.509 *$ & 0.132 * & $-0.310^{*}$ & 0.161 * & $-0.323 *$ & $0.182 *$ & $-0.335^{*}$ & $0.209 *$ & $-0.397^{*}$ \\
\hline \multicolumn{2}{|c|}{ Mean Risk Free } & 0.151 & -0.451 & 0.098 & -0.253 & 0.133 & -0.290 & 0.136 & -0.271 & 0.172 & -0.358 \\
\hline & & \multicolumn{10}{|c|}{ Risky Debt Models HO: $\gamma_{0}{ }^{*}=\beta_{U}{ }^{*} ; \gamma_{1}^{*}=1$} \\
\hline & Model & $\gamma_{0}-\beta_{U} *$ & $\gamma_{1}-1^{*}$ & $\gamma_{0}-\beta_{U}{ }^{*}$ & $\gamma_{1}-1^{*}$ & $\gamma_{0}-\beta_{U}{ }^{*}$ & $\gamma_{1}-1^{*}$ & $\gamma_{0}-\beta_{U}{ }^{*}$ & $\gamma_{1}-1^{*}$ & $\gamma_{0}-\beta_{U} *$ & $\gamma_{1}-1 *$ \\
\hline$\beta_{D}=0.2$ & $1 \mathrm{~b}$ & 0.153 * & -0.165 & 0.072 & 0.027 & 0.091 & -0.041 & 0.077 & -0.165 & 0.106 & -0.325 * \\
\hline$\beta_{D}=0.3$ & $1 \mathrm{~b}$ & 0.113 & 0.082 & 0.025 & 0.329 & 0.075 & 0.106 & 0.034 & 0.051 & 0.058 & -0.134 \\
\hline \multicolumn{2}{|c|}{ Mean $\Delta \mathbf{1 b}$} & 0.133 & 0.124 & 0.049 & 0.178 & 0.083 & 0.074 & 0.056 & 0.108 & 0.082 & 0.230 \\
\hline$\beta_{D}=0.2$ & 2b Rel & 0.050 & 0.213 & -0.018 & 0.435 * & 0.025 & 0.214 & -0.013 & 0.197 & 0.003 & 0.052 \\
\hline$\beta_{D}=0.3$ & $2 \mathrm{~b}$ Rel & 0.047 & 0.323 & -0.027 & $0.626^{*}$ & 0.005 & 0.428 & -0.043 & 0.453 & -0.032 & 0.305 \\
\hline$\beta_{D}=0.2$ & $2 \mathrm{~b}$ Abs & 0.045 & 0.239 & -0.030 & 0.484 * & 0.004 & 0.327 & 0.010 & 0.083 & 0.019 & -0.018 \\
\hline$\beta_{D}=0.3$ & $2 \mathrm{~b} \mathrm{Abs}$ & 0.042 & 0.358 & -0.040 & 0.706 * & -0.016 & 0.565 & -0.026 & 0.343 & -0.020 & 0.237 \\
\hline \multicolumn{2}{|c|}{ Mean $\Delta$ 2b } & 0.046 & 0.283 & 0.029 & 0.563 & 0.013 & 0.384 & 0.023 & 0.269 & 0.019 & 0.153 \\
\hline$\beta_{D}=0.2$ & 3b Rel & 0.133 & -0.100 & 0.056 & 0.079 & 0.096 & -0.066 & 0.049 & -0.062 & 0.058 & -0.160 \\
\hline$\beta_{D}=0.3$ & $3 b$ Rel & 0.138 & -0.092 & 0.056 & 0.168 & 0.077 & 0.085 & 0.012 & 0.156 & 0.015 & 0.066 \\
\hline$\beta_{D}=0.2$ & $3 \mathrm{~b}$ Abs & 0.128 & -0.079 & 0.044 & 0.124 & 0.076 & 0.021 & 0.071 & -0.144 & 0.075 & -0.215 \\
\hline$\beta_{D}=0.3$ & $3 \mathbf{b}$ Abs & 0.136 & -0.076 & 0.045 & 0.229 & 0.058 & 0.184 & 0.028 & 0.085 & 0.028 & 0.013 \\
\hline \multicolumn{2}{|c|}{ Mean $\Delta 3 b$} & 0.134 & 0.087 & 0.050 & 0.150 & 0.077 & 0.089 & 0.040 & 0.112 & 0.044 & 0.114 \\
\hline$\beta_{D}=0.2$ & $\operatorname{Rel} \mathrm{T}_{\mathrm{C}}$ & & & & & & & & & & \\
\hline$q=3 \%$ & $4 b$ & 0.125 & -0.148 & 0.052 & -0.015 & 0.102 & -0.179 & 0.068 & -0.210 & 0.086 & $-0.317^{*}$ \\
\hline$q=7 \%$ & $4 b$ & 0.136 & -0.190 & 0.063 & -0.066 & 0.114 & -0.222 & 0.081 & $-0.262 *$ & 0.100 & -0.369 * \\
\hline$q=11 \%$ & $4 b$ & 0.147 & -0.230 & 0.073 & -0.114 & 0.125 & $-0.262 *$ & 0.095 & -0.308 * & 0.116 & -0.414 * \\
\hline$\beta_{D}=0.3$ & $\operatorname{Rel} \mathrm{T}_{\mathrm{C}}$ & & & & & & & & & & \\
\hline$q=3 \%$ & $4 b$ & -0.009 & 0.309 & -0.071 & 0.336 & 0.029 & -0.013 & 0.050 & -0.241 & -0.024 & -0.072 \\
\hline$q=7 \%$ & $4 b$ & 0.111 & -0.079 & 0.033 & 0.074 & 0.079 & -0.097 & 0.044 & -0.140 & 0.061 & -0.258 \\
\hline$q=11 \%$ & $4 b$ & 0.120 & -0.126 & 0.042 & 0.016 & 0.089 & -0.148 & 0.058 & -0.201 & 0.077 & -0.319 * \\
\hline$\beta_{D}=0.2$ & $A b s \mathrm{~T}_{\mathrm{C}}$ & & & & & & & & & & \\
\hline$q=3 \%$ & $4 \mathrm{~b}$ & 0.122 & -0.141 & 0.047 & -0.004 & 0.085 & -0.114 & 0.094 & -0.298 * & 0.104 & $-0.375^{*}$ \\
\hline$q=7 \%$ & $4 b$ & 0.134 & -0.186 & 0.059 & -0.060 & 0.098 & -0.165 & 0.107 & -0.341 * & 0.119 & -0.420 * \\
\hline $\mathrm{q}=11 \%$ & $4 b$ & 0.146 & -0.228 & 0.070 & -0.111 & 0.110 & -0.212 & 0.119 & $-0.379 *$ & 0.132 & -0.459 * \\
\hline$\beta_{D}=0.3$ & $A b s \mathrm{~T}_{\mathrm{C}}$ & & & & & & & & & & \\
\hline$q=3 \%$ & $4 b$ & 0.098 & -0.016 & 0.016 & 0.160 & 0.050 & 0.036 & 0.052 & -0.164 & 0.061 & -0.249 \\
\hline$q=7 \%$ & $4 b$ & 0.109 & -0.070 & 0.027 & 0.089 & 0.062 & -0.030 & 0.066 & -0.223 & 0.077 & -0.311 * \\
\hline $\mathrm{q}=11 \%$ & $4 b$ & 0.119 & -0.120 & 0.038 & 0.025 & 0.075 & -0.091 & 0.079 & -0.274 * & 0.092 & $-0.365 *$ \\
\hline \multicolumn{2}{|c|}{ Mean $\Delta 4 b$} & 0.115 & 0.154 & 0.049 & 0.089 & 0.085 & 0.131 & 0.076 & 0.253 & 0.087 & 0.327 \\
\hline \multicolumn{2}{|c|}{ Mean Risky Models } & 0.107 & 0.162 & 0.046 & 0.194 & 0.070 & 0.164 & 0.058 & 0.217 & 0.067 & 0.248 \\
\hline
\end{tabular}

The uppercase asterisk * represents a $p$-value $\leq 0.05$. 
The main result that emerges from Table 3 is that according to risky debt models, there is a significant relationship between beta and leverage. This result holds for each of the sample years and for all leverage estimates. All of the additional tests conducted (though not reported here) confirm the results and were significant at the $1 \%$ level.

One finding consistent with previous results involves the use of market measures for capturing the level of the firm's financial risk. Although it is commonly agreed that book measures of financial leverage serve as a good approximation for the degree of financial risk of the firm, this study suggests that an estimation of the market value of equity has better explanatory power in the context of the risk-leverage relationship. In all of the empirical tests and sensitivity analysis we conducted, the $\mathrm{R}^{2}$ values were consistently higher than their corresponding book measures. For example, the mean value of $\mathrm{R}^{2}$ for the Relative and Absolute $\operatorname{Lev}_{2}$ (which are market estimates) was 0.159, and the corresponding mean values for the Relative and Absolute Lev 1 were 0.102 and 0.116 .

Next, we move on to our primary goal by testing the degree to which the observed parameters $\gamma_{0}$ and $\gamma_{1}$ in each model corresponded to their counterpart theoretical models $\gamma_{0}{ }^{*}$ and $\gamma_{1}{ }^{*}$. Again, given that the scale of iteration is extremely high, Table 3 presents only the results for the set of values for the Relative $\mathrm{Lev}_{2}$, when mean debt beta was 0.1 and bankruptcy costs were $7 \%$. However, Table 4 presents additional findings when the mean debt beta were 0.2 and 0.3 , and bankruptcy costs were $3 \%, 7 \%$, and $11 \%$. Using other estimates yielded similar results. As the two last lines in Table 3 for each risky model demonstrate, we accepted the null hypothesis for the equality of the observed intercept and slope with their theoretical counterparts. In other words, H0: $\gamma_{0}=\beta_{\mathrm{U}}$, and $\gamma_{1}=1$ for the intercept and slope, respectively. These results imply that risky debt models capture the real beta-leverage relationship better than risk free debt models. To verify the latter conclusion, for the sake of sensitivity analysis, a more detailed discussion of this issue, combined with additional measures of the parameters, is given in Table 4 and described in the subsequent section.

\subsection{Comparative Analysis and Robustness Tests}

We turn now to testing the approximation of the observed values relative to their theoretical counterparts. Recall that we tested each regression model outlined in Section 3 (that is, Model (1a)-(4b)) directly and then compared the observed parameters $\left(\gamma_{0}\right.$ and $\left.\gamma_{1}\right)$ to the theoretical values $\left(\gamma_{0}{ }^{*}\right.$ and $\gamma_{1}^{*}$, which are hypothesized to equal $\beta_{U}$ and 1, respectively, for the risky debt models, and $\beta_{U}$ for the risk free models) derived from the hypotheses mentioned earlier in Section 3.

For example, the formulation of Model ( $2 b)$ is as follows:

$$
\beta_{\mathrm{E}, \mathrm{i}}=\beta_{\mathrm{U}, \mathrm{i}}+\left[\left(\beta_{\mathrm{U}}-\beta_{\mathrm{D}}\right)\left(1-\mathrm{T}_{\mathrm{C}}\right) \mathrm{L}\right]_{\mathrm{i}}+\mathrm{u}_{\mathrm{i}}
$$

We tested this formulation using the regression in Equation (8):

$$
\beta_{\mathrm{E}, \mathrm{i}}=\gamma_{0}+\gamma_{1}\left[\left(\beta_{\mathrm{U}}-\beta_{\mathrm{D}}\right)\left(1-\mathrm{T}_{\mathrm{C}}\right) \mathrm{L}\right]_{\mathrm{i}}+\varepsilon_{\mathrm{i}}
$$

Given that the explanatory variable in Equation (8) is the term in the squared parentheses $\left[\left(\beta_{U}-\right.\right.$ $\left.\left.\beta_{D}\right)\left(1-T_{C}\right) L\right]$, the null hypothesis here is that $\gamma_{1}$ equals 1 , which is expressed as $\gamma_{1}{ }^{*}$. Accordingly, $\gamma_{0}$ should be equal to $\beta_{\mathrm{U}}$, which is derived from the theoretical Model ( $\left.2 b\right)$. As described in Section 3 , Model (2a) is a risk free debt model, and Model (2b) is a risky debt model. In addition, while the null hypothesis in Equation (10) is that both $\gamma_{0}$ and $\gamma_{1}$ should be equal $\beta_{\mathrm{U}^{*}}$, the null hypothesis in Equation (8) is that $\gamma_{0}$ will equal $\beta_{U^{*}}$ and $\gamma_{1}$ will equal the value of 1 . Therefore, the gaps are as follows: $\left[\gamma_{0}-\right.$ $\left.\beta_{U^{*}}\right]$ and $\left[\gamma_{1}-\beta_{U^{*}}\right]$ for the risk free models, and $\left[\gamma_{0}-\beta_{U}^{*}\right]$ and $\left[\gamma_{1}-1^{*}\right]$ for the risky debt models.

Table 4 presents the differences tests for the observed and theoretical parameters. The results are given when Relative $\mathrm{Lev}_{2}$ is used. The first and second columns describe the model and the variants in its variables. Each year is divided into two columns. The first column shows the difference between $\gamma_{0}$ and its theoretical value by the null hypothesis, which is $\beta_{\mathrm{U}}{ }^{*}$. The second column presents the difference between $\gamma_{1}$ and its theoretical value, which is also $\beta_{U}^{*}{ }^{*}$ for the risk free models and 1 for the 
risky debt models. The upper part of Table 4 lists the results obtained for the risk free debt models (Models (1a)-(3a)) and the bottom part lists them for the corresponding risky debt models ((Models (1b)-(4b)).

Table 4 presents the differences tests conducted for each regression parameter, followed by sensitivity tests for different $T_{C}, \beta_{D}$, and q measures. Each sample year in Table 4 is divided into two columns according to the statistical tests conducted for the differences between the observed regression intercepts and slopes and their theoretical counterparts. It is important to note that the value of $\beta_{U^{*}}$ is the theoretical $\beta_{U}$ that should have been revealed in the estimation results if the specific model holds true. Each $\beta_{U}{ }^{*}$ is derived from the specific model and according to the relevant measures of market imperfections. Each line in Table 4 specifies the exact model tested with reference to the sensitivity analysis conducted. For example, the fourth line in the risk free debt models presents the empirical results achieved by testing Model (3a), according to the Relative corporate tax estimation method described in detail in Section 4. To summarize, Table 4 presents the significance tests for the differences between the observed parameters and their counterpart theoretical values, namely, $\left[\gamma_{0}-\beta_{U^{*}}\right]$ and $\left[\gamma_{1}\right.$ $\left.-\beta_{U^{*}}\right]$ for the risk free debt models and $\left[\gamma_{0}-\beta_{U^{*}}\right]$ and $\left[\gamma_{1}-1^{*}\right]$ for the risky debt models. The first term of each pair in the squared parentheses represents the deviation of the observed intercept from its corresponding theoretical value, and the second term represents the deviation of the observed slope from the value of its theoretical counterpart. Note that for all risky debt models, $\gamma_{1}$ should be equal to $\gamma_{1}{ }^{*}$, which is the value of 1 . Finally, the last line in Table 4 presents the overall mean. Other financial leverage estimates as well as the beta of debt and bankruptcy costs were also tested and yielded similar results, so we do not report them here.

We started, for example, with the comparison of $\gamma_{0}$ to $\beta_{U^{*}}$ in 2006. In accordance with previous results with regard to the estimation of $\beta_{U}$, Model $(4 b)$ was more accurate than any risk free model. While most of the differences were significant in 2006 for the risk free models, all of the gaps were insignificant in Model (4b). Furthermore, the mean gap in Model (4b) was 0.049, while the mean gap for the risk free models was 0.098 . Therefore, using Model (4b) reduced the deviation by nearly $48 \%$. A similar picture emerges when we compare any of the risk free models to Model ( $4 \mathrm{~b})$ across the sample years. While the majority of the tests conducted point to the significance of $\left[\gamma_{0}-\beta_{U^{*}}\right]$ for the risk free models, all of these gaps are insignificant for Model (4b). Similar results emerge when we compare $\gamma_{1}$ to $\gamma_{1}^{*}$. While most of the risk free models imply that $\gamma_{1}$ is significantly different from its theoretical counterpart, the opposite is true for Model (4b). In 2006, for example, four of the five tests conducted for the risk free models showed a significant difference between $\gamma_{1}$ and $\gamma_{1}^{*}\left(\left[\gamma_{1}-1^{*}\right]\right)$. However, for Model (4b), none of the tests showed a significant difference. These results imply that Model $(4 b)$ is preferable to the risk free models. Furthermore, a comparison between the mean gap of Model $(4 \mathrm{~b})$ and the other risky models demonstrates that Model (4b) has the minimum mean value for the difference between $\gamma_{1}$ and $\gamma_{1}{ }^{*}\left(\left[\gamma_{1}-1^{*}\right]\right)$. The mean absolute value of the difference for Model $(4 \mathrm{~b})$ was 0.089 and 0.194 for the rest of the three risky debt models, which improved the accuracy in this case by nearly $54 \%$ (note that we computed the mean value of the absolute differences rather than their natural values to avoid the possible bias of positive and negative gaps). However, this result holds only for 2005-2007. The improvement was even greater when we compared the value of 0.089 to the corresponding mean value of the risk free models, which was 0.253 (in absolute terms). The improvement in this case was nearly $64 \%$. This rate of improvement is evident in each year of the sample. In fact, most of the results across the years show that the gap between $\gamma_{1}$ and $\gamma_{1}{ }^{*}$ is minimized when debt is considered risky rather than risk free.

Thus, Table 4 indicates that risky models seem to be preferable in the context of this research study. Another illustration of the supremacy of risky debt models emerges from comparing the direct estimation of Model (3a) vs. Model (3b). For example, in 2006, the differences between -0.289 and -0.310 of $\left[\gamma_{1}-\beta_{U}^{*}\right]$ in the risk free model of Model (3a) were considerably higher than those of Model (3b), where the corresponding differences were 0.079 through 0.229 for $\left[\gamma_{1}-1^{*}\right]$. It is important to 
underscore that these differences were statistically significant for Model (3a) (that is, the observed slope was statistically different from the theoretical slope), while for Model (3b) they were not.

Having established the supremacy of the risky debt models, one might ask which risky debt model best demonstrates the beta-leverage relationship. Although the differences in the final results were not large, considering both the significance of the differences and their scale (the mean value of the difference), Model ( $2 b$ ) and Model (3b) exhibited quite similar results with a small preference for Model (4b). In other words, although generally the difference between the theoretical and observed values in the estimation of Model (4b) was not significant, implying that this model holds true, the final conclusion is not straightforward. There is also support for other risky debt models. However, one conclusion is clear. There is strong evidence that risky debt models are a more accurate representation of the beta-leverage relationship.

Another important consideration that emerges from the robustness tests (although not reported here) is the use of market leverage measures. Although the book measures support risky debt expressions, the market estimates of financial leverage seem to have had more accuracy in the context of this research study. However, regardless of whether book or market measures are used, the consideration of risky debt is important.

\section{Summary and Conclusions}

The goal of this study was to directly test the sustainable relationship between beta and leverage that has been theorized in the literature, and the extent to which this relationship is sustainable with respect to various types of market imperfections that have not been considered previously. We examined models that included corporate and personal taxes as well as risky debt and bankruptcy costs. To our knowledge, this is the first time that such a thorough and direct analysis has been conducted. In addition, previous studies have not considered the impact of personal taxes or bankruptcy costs, nor estimated the variables representing taxes and debt riskiness directly. Moreover, the incorporation of risky debt, if done at all, has been only implicit, and not explicit. Finally, these studies are relatively old, covering no data after 1988.

In contrast, we tested various models assuming that debt is or is not risky using a sample of industrial firms traded on the NYSE. Given the impact of debt on asset values in the recent world crisis, this study sought to determine empirically whether the impact of financial leverage on equity risk corresponded to the risk free models of Hamada [3] and Rubinstein [5], or to the theoretical relationship posited by Conine [6] and Yagil [7]. The question of the riskiness of debt has important implications for corporate managers, financial analysts, and policy makers.

Given that direct tests are relatively rare and that we have conducted exhaustive tests using a broad number of variables, we maintain that this study is a thorough examination of the relationship between financial leverage and the systematic risk of the equity shareholders.

The research leads to several conclusions. First, our tests support Yagil's [7] theoretical model, expressed here as Model (4b), which states that the relationship between financial leverage and equity risk involves both corporate and personal taxes as well as risky debt and bankruptcy costs. While the empirical tests here also support Model (2b) and Model (3b), Model (4b) is preferable in that it had more cases where the differences between the observed parameters and their theoretical counterparts were insignificant. Second, we argue that attention should be paid to market measurements when constructing financial leverage variables. This study suggests that market estimates can serve as a better proxy for financial risk than book measures. All of our sensitivity analyses and robustness tests underscore that point. Therefore, future studies should examine the beta-leverage relationship by evaluating the market value of debt. Additionally, due to data availability, our sample time period was relatively old. Therefore, a re-examination of the models using the approach suggested in this paper can be conducted in a future study by employing a more recent dataset.

The main implication from this study is that using risk free debt models might lead to biased beta estimates, resulting in inaccurate and unsustainable estimates of the cost of capital and incorrect 
capital budgeting decisions. Inaccurate beta estimates or beta adjustments may also adversely affect the precision of performance measures such as those of Jensen and Treynor. In this respect, the results of this study might have consequences on the recently growing area of sustainable finance in the sense that investment decisions made by different bodies and institutions in the country are more consistent with market imperfections (examined in this study) that exist in the economy. In other words, our findings can be in line with a sustainable financial marketplace that contributes to the economic efficiency in the long run and can be related to social well-being. The implications of this study can also be related to activities that fall under the heading of sustainable finance such as microfinance, impact investing, and the development of the financial system in a more sustainable way.

Author Contributions: The authors contributed equally to the paper in terms of theory and literature review, research design, empirical procedures and academic writing.

Funding: This research received no external funding

Acknowledgments: We would like to thank the anonymous referees for their comments and suggestions on the previous version of this paper. The remaining errors are our responsibility.

Conflicts of Interest: The authors declare no conflicts of interest.

\section{References}

1. Modigliani, F.; Miller, M.H. The Cost of Capital, Corporation Finance and the Theory of Investment. Am. Econ. Rev. 1958, 48, 261-297.

2. Modigliani, F.; Miller, M.H. Corporate income taxes and the cost of capital: A correction. Am. Econ. Rev. $1963,53,433-443$.

3. Hamada, R.S. Portfolio analysis, market equilibrium, and corporation finance. J. Financ. 1969, 24, 13-31. [CrossRef]

4. Hamada, R.S. The effect of the firm's capital structure on the systematic risk of common stocks. J. Financ. 1972, 27, 435-452. [CrossRef]

5. Rubinstein, M.E. A mean variance synthesis of corporate financial theory. J. Financ. 1973, 28, 167-181. [CrossRef]

6. Conine, T.E. Corporate debt and corporate taxes: An extension. J. Financ. 1980, 35, 1033-1037. [CrossRef]

7. Yagil, Y. On valuation, beta, and the cost of equity capital: A note. J. Financ. Quant. Anal. 1982, 17, 441-449. [CrossRef]

8. Bowman, R.G. The importance of a market-value measurement of debt in assessing leverage. J. Account. Res. 1980, 18, 242-254. [CrossRef]

9. Chance, D. Evidence on a Simplified Model of Systematic Risk. Financ. Manag. 1982, 11, 53-63. [CrossRef]

10. Marston, F.; Perry, S. Implied Penalties for Financial Leverage: Theory versus Empirical Evidence. Q. J. Bus. Econ. 1996, 35, 77-97.

11. Beaver, W.H.; Kettler, P.; Scholes, M. The association between market determined and accounting-determined risk measures. Account. Rev. 1970, 45, 654-682.

12. Bildersee, J.S. The Association between a Market-Determined Measure of Risk and Alternative Measures of Risk. Account. Rev. 1975, 50, 81-98.

13. Myers, $\mathrm{S}$. The relationship between real and financial measures of risk and return. In Risk and Return in Finance; Friend, I., Bicksler, J., Eds.; Ballinger Publishing Company: Cambridge, UK, 1977.

14. Gahlon, J.; Gentry, J. On the relationship between systematic risk and the degree of operating and financial leverage. Financ. Manag. 1982, 11, 15-23. [CrossRef]

15. Mandelker, G.; Rhee, S. The impact of the degrees of operating and financial leverage on systematic risk of common stocks. J. Financ. Quant. Anal. 1984, 19, 45-57. [CrossRef]

16. Darrat, A.F.; Mukherjee, T.K. Inter-industry differences and the impact of operating and financial leverages on equity risk. Rev. Financ. Econ. 1995, 4, 141-155. [CrossRef]

17. Lin, C.; Schmid, T.; Xuan, Y. Employee representation and financial leverage. J. Financ. Econ. 2018, 127, 303-324. [CrossRef]

18. Vo, X.V. Leverage and corporate investment-Evidence from Vietnam. Financ. Res. Lett. 2019, 28, 1-5. [CrossRef] 
19. Kini, O.; Shenoy, J.; Subramaniam, V. Impact of financial leverage on the incidence and severity of product failures: Evidence from product recalls. Rev. Financ. Stud. 2016, 30, 1790-1829. [CrossRef]

20. Bărbuță-Mișu, N.; Madaleno, M.; Ilie, V. Analysis of Risk Factors Affecting Firms' Financial Performance-Support for Managerial Decision-Making. Sustainability 2019, 11, 4838. [CrossRef]

21. Di Pietro, F.; Bontempi, M.E.; Palacín-Sánchez, M.J.; Samaniego-Medina, R. Capital Structure across Italian Regions: The Role of Financial and Economic Differences. Sustainability 2019, 11, 4474. [CrossRef]

22. Lassala, C.; Apetrei, A.; Sapena, J. Sustainability matter and financial performance of companies. Sustainability 2017, 9, 1498. [CrossRef]

23. Saretto, A.; Tookes, H.E. Corporate Leverage, Debt Maturity, and Credit Supply: The Role of Credit Default Swaps. Rev. Financ. Stud. Forthcom. 2013, 26, 1190-1247. [CrossRef]

24. Denis, D.J.; McKeon, S.B. Debt Financing and Financial Flexibility Evidence from Proactive Leverage Increases. Rev. Financ. Stud. 2012, 25, 1897-1929. [CrossRef]

25. Giroud, X.; Mueller, H.M.; Stomper, A.; Westerkamp, A. Snow and leverage. Rev. Financ. Stud. 2012, 25, 680-710. [CrossRef]

26. George, T.J.; Hwang, C.Y. A resolution of the distress risk and leverage puzzles in the cross section of stock returns. J. Financ. Econ. 2010, 96, 56-79. [CrossRef]

27. Brav, O. Access to capital, capital structure, and the funding of the firm. J. Financ. 2009, 64, $263-308$. [CrossRef]

28. Lemmon, M.L.; Roberts, M.R.; Zender, J.F. Back to the beginning: Persistence and the cross-section of corporate capital structure. J. Financ. 2008, 63, 1575-1608. [CrossRef]

29. Chang, X.; Dasgupta, S. Target behavior and financing: How conclusive is the evidence. J. Financ. 2009, 64, 1767-1796. [CrossRef]

30. Frank, M.Z.; Goyal, V.K. Capital Structure Decisions: Which Factors Are Reliably Important? Financ. Manag. 2009, 38, 1-37. [CrossRef]

31. Billet, M.; King, T.D.; Mauer, D.C. Growth opportunities and the choice of leverage, debt maturity, and covenants. J. Financ. 2007, 62, 697-730. [CrossRef]

32. Barclays, M.J.; Morellec, E.; Smith, C.J. On the debt capacity of growth options. J. Bus. 2006, 79, 37-58. [CrossRef]

33. Fama, E.F.; French, K. 'Financing Decision: Who Issues Equity'. J. Financ. Econ. 2005, 76, 549-582. [CrossRef]

34. Molina, C.A. Are firms underleveraged? An examination of the effect of leverage on default probabilities. J. Financ. 2005, 60, 1427-1459. [CrossRef]

35. Aharon, D.Y.; Yagil, Y. The Impact of Financial Leverage on the Cost of Equity. Int. J. Econ. Financ. Issues 2019, 9, 175-188.

36. Aharon, D.Y.; Yagil, Y. The Impact of Financial Leverage on the Variance of Stock Returns. Int. J. Financ. Stud. 2019, 7, 14. [CrossRef]

37. Boquist, J.A.; Racette, G.A.; Schlarbaum, G.G. Duration and risk assessment for bonds and common stocks. J. Financ. 1975, 30, 1360-1365. [CrossRef]

38. Lanstein, R.; Sharpe, W. Duration and Security Risk. J. Financ. Quant. Anal. 1978, 13, 653-668. [CrossRef]

39. Livingston, M. Duration and Risk Assessment for Bonds and Common Stocks: A Note. J. Financ. 1978, 33, 293-295.

40. Reilly, F.K.; Joehnk, M.D. The Association Between Market-Determined Risk Measures for Bonds and Bond Ratings. J. Financ. 1976, 31, 1387-1403.

41. Alexander, G.J. Applying the market model to long term corporate bonds. J. Financ. Quant. Anal. 1980, 15, 1063-1080. [CrossRef]

42. Weinstein, M. The Systematic Risk of Corporate Bonds. J. Financ. Quant. Anal. 1981, 16, 257-278. [CrossRef]

43. Cornell, B.; Green, K. The investment performance of low-grade bond funds. J. Financ. 1991, 46, $29-48$. [CrossRef]

44. Conine, T.E.; Tomarkin, M. Divisional cost of capital estimation: Adjusting for leverage. Financ. Manag. 1985, 14, 54-58. [CrossRef]

45. Bernardo, A.E.; Chowdhry, B.; Goyal, A. Growth options, beta, and the cost of Capital. Financ. Manag. 2007, 36, 5-17. [CrossRef]

46. Cooper, I.A.; Nyborg, K.G. The value of tax shields is equal to the present value of tax shields. J. Financ. Econ. 2006, 81, 215-225. [CrossRef] 
47. Cooper, I.A.; Nyborg, K.G. Tax adjusted discount rates with investor taxes and risky debt. Financ. Manag. 2008, 37, 365-379. [CrossRef]

48. Doshi, H.; Jacobs, K.; Kumar, P.; Rabinovitch, R. Leverage and the Cross-Section of Equity Returns. J. Financ. 2019, 74, 1431-1471. [CrossRef]

49. Arena, M.P.; Roper, A.H. The effect of taxes on multinational debt location. J. Corp. Financ. 2010, 16, 637-654. [CrossRef]

50. Dyreng, S.; Hanlon, M.; Maydew, E. The effects of executives on corporate tax avoidance. Account. Rev. 2010, 85, 1163-1189. [CrossRef]

51. Fan, J.P.; Titman, S.; Twite, G. An International Comparison of Capital Structure and Debt Maturity Choices. J. Financ. Quant. Anal. 2012, 47, 23-56. [CrossRef]

52. Kemsley, D.; Nissim, D. Valuation of the debt-tax shield. J. Financ. 2002, 57, 2045-2073. [CrossRef]

53. DeAngelo, H.; DeAngelo, L.; Whited, T. Capital structure dynamics and transitory debt. J. Financ. Econ. 2011, 99, 235-261. [CrossRef]

54. Butler, K.C.; Mohr, R.M.; Simonds, R.R. The Hamada and Conine Leverage Adjustments and the Estimation of Systematic Risk for Multisegment Firms. J. Bus. Financ. Account. 1991, 18, 885-901. [CrossRef]

55. Dhaliwal, D.; Heitzman, S.; Li, O. Taxes, leverage, and the cost of equity capital. J. Account. Res. 2006, 44, 691-723. [CrossRef]

56. Van Binsbergen, J.; Graham, J.; Yang, J. The cost of debt. J. Financ. 2010, 65, 2089-2136. [CrossRef]

57. Graham, J. Do personal taxes affect corporate financing decisions. J. Public Econ. 1999, 73, 147-185. [CrossRef]

58. Warner, J.B. Bankruptcy, Absolute Priority, and the Pricing of Risky Debt Claims. J. Financ. Econ. 1977, 4, 239-276. [CrossRef]

59. Weiss, L.A. Bankruptcy resolution: Direct costs and violation of priority of claims. J. Financ. Econ. 1990, 27, 285-314. [CrossRef]

60. Miller, M.H. Debt and taxes. J. Financ. 1977, 32, 261-275.

61. Altman, E. A further empirical investigation of the bankruptcy cost question. J. Financ. 1984, 39, 1067-1089. [CrossRef]

62. Andrade, G.; Kaplan, S.N. How costly is financial (not economic distress)? Evidence from highly leveraged transactions that became distressed. J. Financ. 1998, 53, 1443-1494. [CrossRef]

63. Lubben, S.J. The direct costs of corporate reorganization: An empirical examination of professional fees in large Chapter 11 cases. Am. Bankruptcy Law J. 2000, 509, 508-552.

64. Bris, A.; Welch, I.; Zhu, N. The costs of bankruptcy: Chapter 7 liquidations vs. Chapter 11 reorganizations. J. Financ. 2006, 61, 1253-1303. [CrossRef]

65. Garlappi, L.; Yan, H. Financial Distress and the Cross-section of Equity Returns. J. Financ. 2011, 66, 789-822. [CrossRef]

66. Hortaçsu, A.; Matvos, G.; Syverson, C.; Venkataraman, S. Indirect Costs of Financial Distress in Durable Goods Industries: The Case of Auto Manufacturers. Rev. Financ. Stud. 2013, 26, 1248-1290. [CrossRef]

(C) 2019 by the authors. Licensee MDPI, Basel, Switzerland. This article is an open access article distributed under the terms and conditions of the Creative Commons Attribution (CC BY) license (http://creativecommons.org/licenses/by/4.0/). 